NBER WORKING PAPER SERIES

IMMIGRATION, INDUSTRIAL REVOLUTION AND URBAN GROWTH IN THE UNITED STATES, 1820-1920: FACTOR ENDOWMENTS, TECHNOLOGY AND GEOGRAPHY

\author{
Sukkoo Kim \\ Working Paper 12900 \\ http://www.nber.org/papers/w12900 \\ NATIONAL BUREAU OF ECONOMIC RESEARCH \\ 1050 Massachusetts Avenue \\ Cambridge, MA 02138 \\ February 2007
}

I thank Kei-Mu Yi and seminar participants at the 2006 Regional Science Association meetings in Toronto, St. Louis Federal Reserve, and Philadelphia Federal Reserve for their comments. Financial support from Washington University is gratefully acknowledged. The views expressed herein are those of the author(s) and do not necessarily reflect the views of the National Bureau of Economic Research.

(C) 2007 by Sukkoo Kim. All rights reserved. Short sections of text, not to exceed two paragraphs, may be quoted without explicit permission provided that full credit, including $\odot$ notice, is given to the source. 
Immigration, Industrial Revolution and Urban Growth in the United States, 1820-1920: Factor

Endowments, Technology and Geography

Sukkoo Kim

NBER Working Paper No. 12900

February 2007

JEL No. F2,J2,N3,N6,O30

\begin{abstract}
$\underline{\text { ABSTRACT }}$
Industrial revolution is fundamentally linked with the rise of factories and the decline of skilled artisans in manufacturing. Most scholars agree that factories as compared to artisan shops were intensive in unskilled labor. Indeed, the hallmark of the early factories is the utilization of division of labor of relatively unskilled workers. This paper explores whether the massive influx of unskilled immigrants between 1840 and 1920, by significantly increasing the ratio of unskilled to skilled labor endowment, contributed to the growth and spread of factory manufacturing in the United States. The data indicate that immigration not only contributed to the growth and spread of factories but it also contributed to the growth of cities.
\end{abstract}

\title{
Sukkoo Kim
}

Department of Economics

Washington University

One Brookings Drive

St. Louis, MO 63130-4899

and NBER

soks@artsci.wustl.edu 


\section{Introduction}

The century between 1820 and 1920 defined America as a nation of immigrants or a "melting pot." During this century, more than 33 million people entered the ports of the United States. Immigrants from Europe came in massive waves until the era of open immigration ended with the passage of the 1921 Emergency Quota Act (Figure 1). ${ }^{1}$ By the end of the first three decades of immigration, the census of 1850 finds that almost $10 \%$ of Americans was foreignborn. The share of the foreign-born population fluctuated around 13-15\% between 1860 and 1920, but immigrants and their children represented $30-40 \%$ of the white population (Figure 2). With the passage of the Immigration Act of 1965, immigration rose steadily during the last three decades. However, this recent wave of immigration pales in comparison to that of the earlier waves in duration and in terms of the share of aggregate population (Figure 3 ).

What impact did immigration have on the American economy during the era of mass immigration? Goldin (1994) and Hatton and Williamson (1998) find that immigrants and natives were substitutes; immigration lowered native wages and displaced natives from the northeastern United States where immigrants largely settled. ${ }^{2}$ Studies on immigrant assimilation generally find that immigrants earned lower wages on arrival but provide different assessments on their rates of assimilation. While Hannon (1982), Eichengreen and Gemery (1986) and Hanes (1996) find that wage growth among immigrants was slower than native-born workers, Blau (1980), Hatton (1997), and Minns (2000) find that immigrants experienced faster wage growth than

\footnotetext{
1 The movement to restrict immigration in the U.S. started in the late nineteenth century. Between 1897 and 1917 , the House and the Senate passed numerous bills on literacy tests which finally became law in 1917. When literacy tests proved to be ineffective in curbing immigration, the Congress moved toward a quota system. See Hingham (1955) and Goldin (1994).

2 Friedberg and Hunt (1995) provide an excellent summary of the literature, especially of works on the impact of immigration on the second half of the twentieth century. Most studies on recent immigration find that immigrants and natives are substitutes. Some studies such as Borjas (1999) and Borjas, Freeman and Katz (1997) find large negative impact whereas Card (2001) finds small impact. On the other hand, Ottaviano and Peri (2005a, 2000b)
} 
native-born and caught up to native-born level of earnings within 20 or 25 years. For the

antebellum period, Ferrie (1999) finds that immigrants were geographically, occupationally and

financially mobile. ${ }^{3}$ However, from an aggregate perspective, because American real wages rose

steadily between 1820 and 1920, many scholars such as Goldin (1994) point to the absorptive

capacity of the American economy (Figure 4). ${ }^{4}$

In this paper, I explore whether immigration had a more fundamental impact on the

American economy between 1860 and 1920. In particular, I investigate whether immigration

during this period had a significant impact on the growth and spread of factory organization in

manufacturing. Between 1820 and 1840, when factory production was still in its infancy in

America, immigration may have hindered the spread of factories as many skilled European

artisans sought refuge from the spread of European factory production by moving to America.

Immigration after 1840, however, is likely to have contributed to the growth of factories as it significantly increased the unskilled to skilled labor endowment in America. Because factory

production utilized unskilled workers intensely, the dramatic increase in unskilled to skilled labor endowment ratio is likely to have had a significant impact on the growth of factory

argue that immigrants and natives are complements and that immigrants had a positive impact on native wages. 3 Ferrie (1999) provides a richly detailed study of the immigrant experience by constructing a sample of immigrants from passenger ship lists who entered through New York city in the 1840s and located in the census of populations in 1850 and 1860. By 1850, most immigrants reached their intended destinations (New York, Ohio, and Pennsylvania) and only $17 \%$ remained in the vicinity of New York city. Relative to the native population, immigrants were initially disproportionately represented as skilled artisans and unskilled laborers. About a quarter of immigrants moved downwards in occupational status, but the dominant tendency was to move upwards. The Irish, compared to the British and Germans, were least mobile both geographically and occupationally.

4 Data on real wages were constructed from various sources such as Coombes (1926), Aldrich and Week's series from Long (1960), Rees (1961), Lebergott (1964), and Margo (2000). The nominal values were converted to real wages using the BLS CPI from the Historical Statistics of the United States (1975). Aldrich, Weeks, Rees, and Lebergott series are the average earnings in all manufacturing, Coombes series is the average earnings of unskilled workers in manufacturing, and Margo series is the average earnings of common laborers in the Northeast. The ratio of skilled to unskilled wages seems to have fluctuated without any visible trend between 1820 and 1860 based on the ratio of wages of artisans and common laborers in the Northeast (Margo (2000)) but seems to have narrowed between 1890 and 1940 (Goldin and Katz (1999), Goldin and Margo (1992)). Also see Williamson and Lindert (1980). 
production in the United States. ${ }^{5}$

The industrial revolution, which began in England and spread to elsewhere in Europe and to the United States, is fundamentally linked with the rise of factories and the decline of skilled artisans in manufacturing (Mokyr (2002)). While there are many theories on the rise of factories, this paper emphasizes the importance of the unskilled intensity of factory production. ${ }^{6}$ It is widely believed that factories substituted skilled artisans with the division of labor of unskilled workers who specialized in a limited number of tasks (Sokoloff (1984), Atack (1987), Goldin and Katz (1998), Atack, Bateman and Margo (2005)). ${ }^{7}$ In the United States, in the early industrial period (1820-1840), factories in New England utilized the unskilled labor of women and children (Goldin and Sokoloff (1982)); however, in the second industrial revolution (18601920), unskilled immigrant laborers were the dominant factory manufacturing labor force.

5 Beginning with Habakkuk (1962), there is an extensive literature on skilled-biased technology in American history. For Habakkuk, labor scarcity rather than immigration of unskilled workers caused the early adoption of mechanized factory production in America as compared to Britain. For Rosenberg (1972), the American system of manufacturing was biased toward resource intensive technologies due to its abundant resources. Goldin and Katz (1998) interpret the works of James and Skinner (1985) and Cain and Patterson (1986) as providing evidence for the existence of technology-unskilled complementarity in the nineteenth century U.S. manufacturing. These works indicate that physical capital, raw material and unskilled labor were complements and that they substituted for skilled artisans. To the contrary, Williamson and Lindert (1990) argue that physical capital was a complement to skilled rather than to unskilled labor during this period (also see Temin (1966) and David (1975)). In this paper, I highlight the role of the relative supplies of skilled and unskilled workers as in Goldin and Katz (1998) and Acemoglu (1998). The empirical estimation in this paper is motivated by Acemoglu's model which predicts that an increase in the supply of unskilled (skilled) workers increases the technologies used by unskilled (skilled) workers. Thomas (1954) and Erickson (1957) believed that immigration contributed to the growth of factories in the U.S. Acemoglu (1998) suggests that the increase in the supply of unskilled workers from villages and Ireland to English cities, as documented by Williamson (1990), may have played a role in the rise of factories in England as well. Finally, Lewis $(2003,2006)$ finds that immigration had an impact on the direction of American technology in the second half of the twentieth century.

6 Mokyr $(1999,2002)$ provides an excellent summary of the literature on the British industrial revolution. Mokyr (2002) examines three main classes of explanations for the rise of factories: fixed costs and physical economies of scale, information costs and incentives and labor effort. However, he argues that the most compelling explanation for the rise of factories is based on ideas developed by Demsetz (1988) and Becker and Murphy (1992), namely that "division of labor is limited by the size of the knowledge set necessary to execute and operate best-practice techniques." While workers possessed different skill endowments, factories served as repository of technical knowledge and reduced the costs of transmitting this knowledge to individual workers.

7 According to Atack, Bateman and Margo (2004), the factory system through division of labor shortened the period of skill acquisition and contributed to the de-skilling of workers. Thus, the factory system was well adapted to utilize the abundance of unskilled immigrant workers. Consistent with the de-skilling hypothesis or the intense utilization of unskilled workers, Atack, Bateman and Margo find that average wages of firms fell with increases in firm size. 
The pace and the skill composition of immigrants differed greatly between the early and late industrial period in the United States (Tables 1 and 2). In the early period of industrialization between 1820 and 1840, the pace of immigration was modest and most of the immigrants were skilled artisans and were relatively wealthy. In the transition period between the early to late industrialization, the rate of immigration rose dramatically and a great majority of immigrants were unskilled farmers, laborers and servants. Although the pace of immigration fluctuated and the sources of immigrants shifted from northwestern to central and southeastern Europe by the second industrial revolution, a majority of immigrants remained unskilled workers. Thus, immigration between 1846 and 1920 significantly increased the unskilled to skilled labor endowment ratio in the United States.

One major issue is whether factory jobs "pulled" immigrants to the United States or whether immigrants endogenously changed the direction of American technology toward factory organization of production. My principal identification strategy rests on the exogeneity or the "push" factor of immigration between 1847-1854, a period which marked the first major wave of mass immigration. Many scholars agree that the most important cause of immigration during this period was the potato famine in Ireland and in other European countries (Ó Gráda and O’Rourke (1997), Cohn (2000), Hatton and Williamson (2005)). The potato famine, caused by $p$. infestans, a fungus-like disease that turns the potato into inedible black mush, reduced the acreage of potato in Ireland from 2.1 million acres in 1845 to a mere 0.3 million in 1847 causing massive deaths and emigration (Ó Gráda (1999), Mokyr (1985)).

The instruments used in this paper are the share of foreign-born population in 1850 and the growth in the foreign-born population between 1850 and $1860 .{ }^{8}$ Because a large share of 
immigration prior to the antebellum period occurred during the famine period, the share of foreign-born population in 1850 should be highly correlated with the share of immigrants induced by the potato famine. The total numbers of immigrants between 1846 and 1850 equaled that of the entire period between 1820 and 1845; in addition, the Irish foreign-born represented almost $43 \%$ of all foreign-born population in 1850 (Gibson and Lennon (1999)). ${ }^{9}$ The growth in the foreign-born population between 1850 and 1860 should also be correlated with the famineinduced immigration as the number of immigrants between 1851 and 1854 were one and a half times greater than the number between 1855 and 1860 .

Data on the occupation of immigrants during the mid-nineteenth century provide little evidence for the proposition that these first wave of immigrants was "pulled" by factory jobs in the United States. Cohn (1992), based on data from passenger lists from ships which arrived in New York between 1836-1853, finds that a majority of English immigrants were unskilled and less than $5 \%$ of them possessed prior industrial experience. ${ }^{10}$ Relative to the English population, immigrants were over-represented as farmers and laborers but under-represented in almost all other occupational categories (Table 3). For a sample of immigrants who came in the $1840 \mathrm{~s}$, Ferrie (1999) finds that a majority of the Irish came as unskilled laborers, the British as unskilled

immigration between 1852 and 1854 sparked by the political repression following the unsuccessful 1848 revolution (Atack and Passell (1994)). In addition, as compared to studies such as Altonji and Card (1991) and others which use historic shares of foreign-born as instruments, the historic level of share of foreign-born in 1850 and the growth of foreign-born population between 1850 and 1860 are much more likely to be exogenous.

9 It is important to note that immigration data between 1820 and 1860 were incomplete and subject to both underand over-enumeration. No data were collected for immigrants arriving from Canada, Mexico and Pacific ports and the data included transients bound for territories outside of the U.S. and double counted merchants and visitors who made more than one return voyage from Europe. Of these factors, the most important factor was the underenumeration of immigration flow through Canada. Between 1810-1839, a large share of immigrants to the United States arrived at St. Lawrence ports (see McClelland and Zeckhauser (1982)). Before 1865, about half of UK immigrants, especially the poor, may have come through Canada because the fare to Canadian maritime ports was less than half of that to American ports (Ferrie (1999)).

10 There is considerable anecdotal evidence that most skilled immigrants were artisans rather than factory managers, mechanics or operatives. As the rise of factory production in Europe displaced artisans in Europe, they moved to America. Thus, the arrival of skilled artisans may have delayed the onset of industrial revolution in American cities. However, as factory production gained momentum in the United States, there is evidence that skilled artisans 
laborers and skilled artisans and Germans as farmers and skilled artisans.

While the long-run ebb and flow of immigration was due to the combination of "push" and "pull" factors, one additional exogenous factor which significantly increased the share of unskilled immigrants is related to major advances in transportation. ${ }^{11}$ First, advances in internal transportation due to railroads provided easy access to major ports for most European populations (Hatton and Williamson (2005)). Second, the advances in steamship technology made the trans-Atlantic travel shorter, safer, and easier to get in and out of secondary ports in the Mediterranean (Cohn (2005), Keeling (1999)). Third, the passenger costs relative to per capita income fell significantly between 1820 and 1860 (Galenson (1984)).

My second identification strategy utilizes the fact that most immigrants entered the United States through New York and used domestic transportation networks to reach their intended destinations. Between 1850 and 1914, 70\% of immigrants arrived via the ports in New York (Keeling (1999)); and many immigrants moved immediately from the port of entry to internal destinations (Ferrie (1999)). Distance from New York city and access to water transportation in 1850 are likely to capture the influence of transportation costs on immigrant settlement patterns. It is important to note that New York city became the dominant mercantile port and later the port of entry for immigrants long before it became an industrial city (Albion (1939)). However, distance from New York city and access to water transportation in 1850 may also be correlated with access to markets for manufacturers.

To determine whether immigrants contributed to the growth and spread of unskilledbiased technology embodied in factory-assembly production, I use data of manufacturing firms drawn from the manuscripts of the decennial censuses between 1850 and 1880 which have been became managers and foreman of factories suggesting complementarities between immigrant artisans and laborers. 
merged with county-level information from the censuses of populations from the same respective years. ${ }^{12}$ Data analysis suggests that immigration between 1850 and 1920 may have had a fundamental impact on the direction of American technology. The data reveal that firms in counties with a higher share of foreign-born were much more likely to be organized as factories and were generally larger. In addition, firms in these counties were also more productive and were likely to pay higher average wages to their workers. Standard tests of the instruments indicate their general validity and that the 2SLS estimates are generally similar to those of ordinary regression estimates.

The paper is organized as follows. Section II presents the model, empirical strategy and data analysis on the impact of immigration on unskilled biased technology as embodied in factories. Section III examines the immigrant diversity of occupations by nationality. Section IV studies immigration and urbanization. Section V concludes.

\section{Endowments and Technology}

Industrial development in the United States exhibited three major production technologies: artisan shops (1790-1820), factory-assembly (1820-1920), and factory-continuous (1920- ). Prior to the industrial revolution, skilled artisans produced the entire product with the help of apprentices and family members. With the industrial revolution, factories hired numerous unskilled workers who specialized in few tasks based on division of labor and few skilled workers who operated machines and supervised workers. In the first half of the twentieth century, however, the factory-continuous method began to replace the factory-assembly system

11 See Thomas (1954) and Hatton and Williamson (1998).

12 The firm-level manuscript data were constructed by Jeremy Atack, Fred Bateman and Thomas Weiss; Michael Haines generously provided the merged data set. For discussions on sampling criteria and other pertinent concerns related to the firm-level data, see Atack and Bateman (1999), Atack, Bateman and Margo (2004, 2005), and Kim 
in a number of industries (Goldin and Katz (1998), Jerome (1924)). Unlike the earlier factories, the new factory-continuous system was intensive in skilled rather than unskilled workers. With the advent of electric motors, mechanization replaced the division of labor of unskilled workers. Whereas Goldin and Katz (1998) examine the shift in production from factory-assembly to the factory-continuous methods, I examine the shift from artisan shop to the earlier factory system based on unskilled division of labor. ${ }^{13}$ The empirics of this paper is motivated by Acemoglu's (1998) model of endogenous technological change. The model assumes that there are two types of workers, skilled $(\mathrm{H})$ and unskilled (L), who supply labor inelastically. The consumption good is produced from two complementary production process, one using skilled and the other using unskilled. Firm level technology, $A_{h}$ or $A_{l}$, is determined by technology employed by the firm where skilled and unskilled workers are assumed to use different technologies. The main result of Acemoglu's model is summarized by the following equation: $A_{h} / A_{l}=f(p, H / L)$ where $p=p_{h} / p_{1}$. In this model, an increase in the relative supply of a skill type will lead to an improvement in the technologies that uses that particular skill type. Thus, an exogenous increase in the supply of skilled (unskilled) workers will lead to an improvement in technologies which utilize skilled (unskilled) workers. ${ }^{14}$

In this paper, I assume that the adoption of the factory method of production signifies the increase in the use of unskilled intensive technology and also assume that the share of foreignborn population $(\mathrm{FB} /(\mathrm{FB}+\mathrm{NB}))$ is a useful measure of the relative supply of unskilled to skilled

(2005).

13 Goldin and Katz (1998) suggests that the growth in the supply of skilled labor due to the sudden growth in high school educated workers may have fueled skilled-biased technology toward the factory-continuous batch production. In addition, the supply of unskilled workers fell dramatically during this period as immigration slowed to a trickle. 14 The intuition of the model is as follows: when there are more unskilled workers, then the market for unskilledcomplementary technologies, such as factories, is larger. As a result, more resources will be devoted to the invention of unskilled-complementary technologies. In this model, Acemoglu (1998) shows that the impact on wages is dynamic. Initially, the shift in supply of unskilled workers will lower unskilled wages; however, as the "directed 
workers $(\mathrm{L} / \mathrm{H})$. The share of foreign-born population is subject to two important sources of measurement errors: (1) not all foreign-born workers are unskilled and (2) not all native-born workers are skilled. However, these measurement errors, to the extent that they are important, are both likely to bias the estimates downwards.

To investigate whether immigration influenced the adoption of factory production in U.S. manufacturing, I estimate the following equations:

(1) Factory $\mathrm{ijc}_{\mathrm{jc}}=\alpha_{0}+\alpha_{1}$ Fgn-Born $_{\mathrm{c}}+\alpha_{2} \mathrm{~F}_{\mathrm{ijc}}+\mathrm{d}_{\mathrm{j}}+\mathrm{d}_{\mathrm{s}}+\mathrm{u}_{\mathrm{ijc}}$

(2) $\ln [\text { Firmsize }]_{\mathrm{ijc}}=\alpha_{0}+\alpha_{1}$ Fgn-Born $_{\mathrm{c}}+\alpha_{2} \mathrm{~F}_{\mathrm{ijc}}+\mathrm{d}_{\mathrm{j}}+\mathrm{d}_{\mathrm{s}}+\mathrm{u}_{\mathrm{ijc}}$

where Factory $_{\mathrm{icc}}$ is equal to 1 if firm size is greater than 15 workers and 0 otherwise, firm size is defined as one plus the number of male, female and child employees, and i, j, c, s indexes firm, industry, county and state, respectively. The independent variables are the share of foreign-born population in county c, firm-level $\left(\mathrm{F}_{\mathrm{ijc}}\right)$ characteristics such as the capital-labor ratio, the share of male workers and whether a firm used steam-power or water-power rather than hand-power. Goldin and Katz (1998) believe that the shift from artisan to factory system probably involved an increase in capital-labor intensity. Since firms in some industries may be more likely organized as factories because of industry-specific differences in fixed cost or because they are located in certain regions with access to specialized raw materials, the regressions include 3-digit industry $\left(\mathrm{d}_{\mathrm{j}}\right)$ and state fixed-effects $\left(\mathrm{d}_{\mathrm{s}}\right)$.

In addition, I estimate whether firms in counties with higher levels of immigrant workers were more productive and paid higher wages using the following equations:

(3) $\ln [\text { Wage }]_{\mathrm{ijc}}=\alpha_{0}+\alpha_{1}$ Fgn-Born ${ }_{\mathrm{c}}+\alpha_{2} \mathrm{~F}_{\mathrm{ijc}}+\mathrm{d}_{\mathrm{j}}+\mathrm{d}_{\mathrm{s}}+\mathrm{u}_{\mathrm{ijc}}$

(4) $\ln [\mathrm{LP}]_{\mathrm{ijc}}=\alpha_{0}+\alpha_{1}$ Fgn-Born $\mathrm{c}+\alpha_{2} \mathrm{~F}_{\mathrm{ijc}}+\mathrm{d}_{\mathrm{j}}+\mathrm{d}_{\mathrm{s}}+\mathrm{u}_{\mathrm{ijc}}$

technology effect" shifts the relative demand of unskilled workers, wages of unskilled workers will rise over time. 
where wage and labor productivity (LP) are average wages and output per worker of firms, respectively. To the extent that immigration leads to the adoption of superior factory-assembly production technologies based on division of labor, workers in immigration abundant counties should be more productive and earn higher wages.

To estimate equations (1)-(4), I use a data set which merges the Atack-Bateman-Weiss (ABW) sample of manufacturing firms drawn from the manuscripts of the decennial censuses for $1850,1860,1870$ and 1880 with the respective U.S. decadal censuses of population. The ABW data set contains information on manufacturing firms such as output, capital, labor, raw materials, wages, and primary power source and are categorized by the standard industrial code at the 3-digit industry level. The county-level census data contain a rich array of information such as population, foreign-born population and various economic and demographic characteristics. The samples were restricted to firms with positive values of output, employment and capital. To eliminate potential outliers in the data, I also excluded firms with gross output less than \$500 and those with extremely low and high wages (Atack, Bateman and Margo (2004), Kim (2006)).

Table 4 presents data on county population characteristics from the censuses of population. The number of counties in the U.S. grew from 1623 to 2613 and the average population of these counties also rose steadily from 14,290 to 19,208. The foreign-born share of the population rose from $5.9 \%$ to $11.5 \%$ between 1850 and 1870 and then fell slightly to $10.7 \%$ in 1880 . The average urban share of the county population rose from $3.8 \%$ to $8.1 \%$ between 1850 and 1880 . From a regional perspective, the share of foreign-born was the highest in the Pacific and Mountain counties followed by Middle Atlantic, East North Central, New England and West North Central counties and was the lowest in the southern counties. The share of 
natives who were born out of state was lowest in counties in New England, Middle Atlantic, South Atlantic and West South Central and rose markedly in counties in the Western regions.

Table 5 shows that factory organization of production and the size of firms in the ABW sample rose from $10 \%$ to $16 \%$ and 4.76 to 5.75 between 1850 and 1880 , respectively. The average nominal wages, labor productivity and capital intensity rose between 1850 and 1870 and then fell slightly in 1880 . Firms that used steam-power increased whereas those that used waterpower decreased over time. The share of male intensity in manufacturing remained constant. Finally, the average percentage of foreign-born of the matched data rose slightly from $13 \%$ to $16 \%$ over time.

As discussed in the introduction, equations (1)-(4) are estimated using two sets of instruments: (1) share of foreign born in 1850 and the change in the share of foreign-born between 1850 and 1860, and (2) distance from New York city and whether a county had access to water transportation in 1850 . In addition, for 1870 and 1880 , years for which county data on the share of foreign-born by countries are provided, I estimate whether the shares of certain ethnic groups such as the Irish or whether immigrant diversity contributed to the growth of factory production in manufacturing.

The first-stage regressions are presented in Table 6. As expected, the percentage of foreign-born in 1850 was highly correlated with the percentages of foreign-born in 1860,1870 and 1880, respectively. A little more surprising is the fact that the change in the growth of foreign-born in 1850 to 1860 are positively correlated with the shares of foreign-born in the later decades. Also as expected, the share of foreign-born populations in 1860, 1870 and 1880 were all negatively correlated with the distance from New York city but were positively correlated with whether a county possessed access to water transportation in 1850 . Finally, the two sets of 
instruments are strong candidates according to Staiger and Watson's (1997) rule of thumb: the first stage F-statistics, testing the hypothesis that coefficients on the instruments are jointly zero, are significantly higher than 10 .

Table 7 reports the probit and ordinary least squares estimates of equations (1)-(4). The probit regression reported in Table 7 shows that counties with a higher share of foreign-born were significantly more likely to have firms organized as factories. ${ }^{15}$ Based on stata's dprobit command which calculates marginal changes in probability for infinitesimal changes in the independent variable (discrete change for dummy variables), the estimated marginal impacts of foreign-born on the factory variable were $0.15,0.32$ and 0.30 for 1860,1870 and 1880 respectively. The marginal impact on factory organization was relatively strong for maleintensity (0.16-0.26) and steam-power dummy (0.11-0.26), moderately important for waterpower dummy (0.01-0.08) but surprisingly weak for capital-labor intensity (0.004-0.01). Regression estimates on firm size indicate similar patterns. In this case, one standard deviation increase in the county foreign-born population increased firm size by $11 \%, 17 \%$ and $14 \%$ in 1860,1870 and 1880, respectively. Firm size is also positively correlated with capital intensity, male intensity, steam and water powered firms. ${ }^{16}$ The regressions on wages and labor productivities show that firms in counties with a higher share of foreign-born paid higher average wages and were characterized by higher labor productivity. ${ }^{17}$ One standard deviation increase in the share of county foreign-born population increased wages and labor productivities

15 The results were robust to the exclusion of Mountain and Pacific states.

16 Atack, Bateman and Margo (2005) explore the relationship between capital intensity and factory organization. 17 Edin, Fredricksson and Åslund (2003) find that ethnic enclaves in Sweden increased the wages of unskilled workers: a standard deviation in concentration increased their wages by $13 \%$. Their evidence based on individual level data suggests that ethnic enclaves provide network effects or provide human capital externalities. My analysis suggests that ethnic enclaves also improve the productivity of firms by lowering the costs of matching heterogeneous workers and firms. Ottaviano and Peri (2005a) find a positive correlation between wages and employment density of U.S.-born workers and linguistic diversity suggesting that a diversity of skills enhances the productivity of a city. 
by 8 to $19 \%$. In terms of firm level characteristics, wages and productivity were positively correlated with capital intensity, male labor intensity and steam-power use, but negatively correlated with utilization of water power.

For 1870 and 1880, the county-level data contain data on the share of immigrants born in different countries as well as data on the share of native-born who migrated from other states. The regression estimates reported in Table 8 indicate that shares of foreign-born from most European countries, such as Ireland, Germany, England and Wales, and Scandinavia, and from British America (Canada) were positively correlated with factory organization and firm size as well as wages and productivity. However, firms in counties with higher shares of foreign-born from Italy were less likely to organize as factories. Interestingly, native in-migration was not associated with factory organization or firm size, but were associated with higher wages and productivity. Finally, ethnic diversity also contributed to factory organization and firm size and was positively correlated with wages and productivity in 1880 but not in $1870 .^{18}$

Tables (9)-(12) present estimates of the instrumental variables regressions. Although not reported for space considerations, the regressions include all the exogenous variables as in Table 7. For both the IVprobit estimates on factory organization and the IV estimates on firm size, the IVprobit or the IV estimates are relatively similar to those of the probit or the OLS estimates except for 1880 when the IV estimates are significantly smaller. However, the IVprobit and IV estimates are higher than the probit or the OLS estimates when the instruments used are the two transportation related variables for 1860 and 1870. For average firm-level wages and productivities, the IV estimates are similar or greater than the OLS estimates, especially when

18 Immigrant diversity is measured using the following standard index of diversity: Diversity $=1 / \Sigma_{\mathrm{i}}\left(\mathrm{FB}_{\mathrm{ij}} / \mathrm{Pop}_{\mathrm{j}}\right)^{2}$ where $\mathrm{FB}_{\mathrm{ij}}$ is foreign-born population from country $\mathrm{i}$ in county $\mathrm{j}$ and $\mathrm{Pop}_{\mathrm{j}}$ is total population in county $\mathrm{j}$. The data contain information on foreign-born from 25-27 countries. 
the instrument used are distance from New York city and water transportation access in 1850. The differences are also significantly greater in 1880 than in the earlier years. Overidentification tests generally indicate the validity of the instruments.

In addition to the formal statistical evidence presented in this paper, there is considerable anecdotal evidence that immigrants played a major role in industrial America. The clothing industry in New York City provides an illustrative example of the impact of immigrant workers on American industries. In the early nineteenth century, clothing was made by artisan tailors assisted by journeymen tailors and apprentices. In New York City, the majority of the 357 clothing entrepreneurs in the Longworth directory in 1816 were artisan tailors. As Feldman (1960, p.90) writes: "The shops were not mechanized and only a few inexpensive tools were needed. Skill, not machinery, was the prerequisite to success for a custom tailor shop.”

Between 1830 and 1850, wholesale manufacturers began to utilize division of labor where few skilled workers were employed as cutters and semi- and unskilled workers were recruited to sew. Although most of the early sewing women were natives, they were quickly displaced by immigrant workers during the period of heavy immigration in the 1840 s. Prior to 1850, most firms operated "inside shops" composed of specialized cutting departments for coats, pants, vests, and trimmings. Sewing was contracted to outside workers. According to Feldman $(1960,97))$, "Brooks employed 78 people on the premises and more than 1,500 outside. Lewis and Hanford in 1849 employed 72 people inside and 3,600 outside." With the introduction of the sewing machine, a good portion of the sewing operation moved inside the shop. In addition, division of labor increased within sewing as workers specialized by plain sewing, stitching, finishing process, embroidering, etc. (See Feldman (1960), Pope (1905), Waldinger (1986), and Burrows and Wallace (1999), and Stott (1990)). 


\section{Immigration and Division of Labor}

Between 1820 and 1920, immigrants to the United States came from a historically unprecedented number of different nations and backgrounds. Immigration not only increased the unskilled to skilled endowment ratio, it also significantly increased the diversity of the labor force. While the vast majority of immigrants was classified in the unskilled category, immigrant workers possessed diversity of prior work experience and physical attributes. Thus, immigration, by increasing the diversity of the workforce, extended the potential for division of labor in society, especially in factories.

Table 13 presents the occupational distribution of the foreign-born by national origins in manufacturing, mining and mechanical industries for 1870 and $1890 .{ }^{19}$ Although the data cannot distinguish artisans from factory occupations, they indicate significant clustering of occupation by nationalities. In 1870, the Germans specialized in many food related industries as brewers, distillers, butchers and confectioners, but they also specialized in other occupations as basket-, cabinet-, cigar-, and piano-makers. The Irish were highly specialized in gas-works and other heavy industries and were employed in manual occupations such as bleachers (textiles), brassfounders, iron-foundry operatives, iron-furnace operatives among others. The English and Welsh were concentrated in textiles, iron and steel, and in certain machine manufacturing. The Scandinavians were highly specialized in a few occupations: sail and awning makers and those

19 The census occupational categories probably understate the extent of ethnic division of labor. Even within occupational categories, there were considerable ethnic specialization. For example, Bodnar, Simon and Weber (1982; 62-63) write: "Italians coming to Pittsburgh had considerable experience in nonagricultural and skilled bluecollar work. These experiences enabled them to secure a variety of occupations while the successful operation of the kin network at the same time funneled Italians into clusters within certain industries. Nearly 60 percent of all adult male Italians were classified as laborers in the 1900 census. Oral interviews and the Pittsburgh Survey of 1907 uncovered several distinct groupings of Italian day laborers. Italians in the steel industry dominated carpentry, repair, and rail shops." 
related to the lumber industry.

While there were some changes in the definitions of occupations between 1879 and 1890 , the data indicate that occupational clustering by nationalities persisted over time. There is considerable overlap in the occupational categories in which Germans, Irish, British, and Scandinavians were over-represented in both 1870 and 1890 . However, there were some major changes as well. Some of these changes were due to the arrival of new immigrant groups such as the Italians. Italians were over-represented in the boot and shoe, charcoal, coke and lime, confectioners, distillers and rectifiers industries among a few others.

Despite the fact that close to one third of the workers in manufacturing and mechanical industries were women in 1890 , the data on occupation by sex reveal limited scope for division of labor for women in manufacturing. ${ }^{20}$ Compared to men's, women's occupations were highly specialized in a few industries. German women were over-represented as bakers; Irish women were mostly servants and were not well represented in manufacturing; British and Canadian (French-speaking) women were most prevalent in textile related occupations. Of the female workers, only the Italian women were specialized in a variety of industries. Consequently, the data suggest that industrialization based on the unskilled labor of native women and children in the United States is likely to been much more muted and confined to a few industries.

\section{Immigration and Urbanization}

The United States transformed from a rural to an urban nation between 1820 and 1920 during the era of mass immigration. Interestingly, the pace of urban growth, especially in central

20 While female labor specialization may have been influenced by discrimination, Goldin's (1990) work suggests that discrimination against female workers in nineteenth century manufacturing was likely to have been relatively unimportant. 
cities, slowed considerably after 1920 as immigration ended. In 1820 , the great majority or $93 \%$

of the population lived in rural areas; by 1920 , a majority or $51 \%$ resided in cities. In the succeeding decades, the share of urban population rose modestly to $57 \%$ in 1940 and then to $64 \%$ in 1960 (Kim (2000)). ${ }^{21}$ It is well known that immigrants were concentrated in cities and were much more likely to live in cities than natives. ${ }^{22}$ In $1870,26.4 \%$ of foreign-born resided in cities with populations greater than 100,000 as compared to $8.1 \%$ of native-born; in 1920 , the figures were $47.7 \%$ and $22.6 \%$ respectively. ${ }^{23}$

In this section, I estimate the extent to which the foreign-born individuals were more likely to reside in cities as compared to the native-born using individual level data from IPUMS for 1880 and 1920. While I do not address the issue of native displacement by the foreign-born, the use of individual level data makes it possible to control for many of the individual level characteristics which contribute to location decisions and should mitigate some of the simultaneity problems. The samples were restricted to individuals who were 16 or older and for those whose urban and literacy statuses were identified. In 1880, the sample consisted of more than 300,000 individuals; in 1920 , the figure was close to 700,000 (Table 14). In $1880,32 \%$ of the individuals in the sample lived in cities; in 1920, the figure was 54.6\%. However, the share of the population who were foreign-born remained near $20 \%$ for both years.

The logistic estimates presented in Table 15 show that the foreign-born were over 3 times

21 There seems to be some correlation between urbanization and establishment plant size. O’Brien (1988) and Kim (1995) show that establishment size by production workers generally rose between 1880 and 1920 and then fell over the second half of the twentieth century for many industries. These trends in plant size may reflect the general shift in manufacturing production from the factory-assembly method based on division of labor to the factory-batch method based on machine mechanization. Since labor recruiting and matching costs were likely to be more important under factory-assembly based on division of labor, manufacturing contributed significantly to urbanization; however, as establishments required fewer and fewer workers, manufacturing became less urbanized. These trends seem consistent with the notion that division of labor was an important reason for why manufacturing became concentrated in cities (Kim (2006)).

22 See Carpenter (1927), Ward (1972) and Bartel (1989).

23 For all urban areas, $61.4 \%$ of foreign-born resided in cities in 1890 as compared to $31.6 \%$ for native-born; in 
more likely to reside in cities in 1880 but that the figure declined somewhat by 1920 . Without any controls, foreign-born were 3.6 and 3 times more likely to reside in cities in 1880 and 1920 respectively. With controls for individual characteristics such as sex, age, marital and literacy statuses, the estimates on foreign-born rose slightly. Women and literate individuals were more likely to reside in cities, but the coefficient on age and marital status depended on occupational and locational fixed effects. When detailed occupational fixed-effects were included in the regression, the foreign-born coefficient declined somewhat. However, the largest decline came, especially in 1920, when the regressions included state fixed-effects.

Did immigrants contribute significantly to urbanization or did they simply displace natives from cities? ${ }^{24}$ Unfortunately, there is no empirical estimate of native urban displacement. However, Hatton and Williamson (1998) find that between 1880 and 1910, 100 foreign-born inmigrants displaced 40 native-born by out-migration in the Northeast region. For the period between 1870 and 1910, Collins (1997) finds a displacement rate of about 4.8 blacks for every 100 foreign-born migrants. ${ }^{25}$ Thus, while immigrants may have displaced some natives, the displacement rate was hardly one for one and the simple fact that immigrants were significantly more likely to reside in cities than natives suggests that immigrants had a fundamental impact on the geography of the American economy in the nineteenth century.

Why did immigrants concentrate in cities? Most likely, immigrants concentrated in cities

1920, the figures were $75.4 \%$ and $47.7 \%$ respectively. See Gibson and Lennon (1999).

24 For the second half of the twentieth century, the evidence is somewhat mixed. Filer (1992) finds that immigrants displaced natives whereas Wright, Ellis and Reibel (1997) find that the displacement of natives from metropolitan areas where immigrants settled were due to reasons other than the inflow of immigrants. 25 Hatton and Williamson (1998) control for state-level employment growth, share of labor force in manufacturing, share of urban population, share of populations aged 15-27, and log of real manufacturing earnings, but do not control for individual level characteristics of natives and foreign-born. If the natives are much more skilled than the foreign-born, then out migration of natives may be unrelated to the inflow of immigrants since natives and foreignborn may be poor substitutes. The displacement figures reported for blacks by Collins (1997) may be more appropriate since the skill levels of immigrants were more likely to resemble those of blacks than native whites; however, the displacement figures for blacks may have been much lower due to discrimination. 
to take advantage of ethnic externalities (Borjas (1995)). Immigrant networks greatly facilitated the transmission of knowledge concerning labor market conditions and skill requirements of their specialized occupations and industries. ${ }^{26}$ Ethnic networks fostered division of labor by immigrant groups. In addition, Kim (2006) suggests that the rise of the labor market and division of labor led to the concentration of firms and workers in cities as they attempted to minimize labor matching costs. Thus, even though many of the first wave of immigrants came from rural Europe, most immigrants became city dwellers in America.

\section{Conclusion}

Ever since Habakkuk (1962), the idea of skilled or unskilled-biased technology has generated significant interest in economics. In recent years, a number of scholars have found evidence of technology-skilled complementarities between computer-based technologies and college educated labor (Autor, Levy and Murnane (2003), Berman, Bound, and Griliches (1994), Autor, Katz and Krueger (1998), Beaudry and Green (2005), among others). ${ }^{27}$ Goldin and Katz (1998) present evidence that technology-skilled complementarity originated with the shift in manufacturing from factory-assembly to factory-batch or continuous production methods and that this shift may have been caused by the rapid rise in American high school education in the

26 There is considerable anecdotal evidence of ethnic division of labor (see Earnst (1949), Rischin (1962), Stott (1990), Ward (1989), Barrett (1987), and Bodnar (1977) to list just a few.)) Bodnar, Simon and Weber (1982) finds that, unlike the Italians and Poles, the blacks were unable to establish occupation networks in Pittsburgh. Because blacks were forced to seek work on their own, they endured substantial periods of unemployment before securing their initial jobs. Also see U.S. Senate (1911): Immigrants in Industries.

27 In an open economy model of trade, a change in factor endowment can have two kinds of impacts: change in mix of production caused by the Rybczynski's theorem and a biased-technological change. Kim (1999) and Hanson and Slaughter (2002) examine the impact of resource endowments on industry-mix. Lewis $(2005,2006)$ finds that local labor supply shocks identified with a component of foreign immigration had little impact on local industry mix but had significant impact in local factor intensity in production. These endogenous changes in technology were also associated with little or no effect on relative wages. To the extent that differences in local factor endowments may cause differences in local technologies, the literature on factor biased-technology provides evidence for the idea that different localities, regions and nations may have different technologies of production (Treffler (1995)). 
early twentieth century (Goldin and Katz (2000), Goldin (2001)).

This paper examines whether immigration, by significantly increasing the unskilled to skilled labor endowment ratio, contributed to the growth and spread of factory production in the second industrial period in the U.S. between 1860 and 1920. The empirical model is motivated by Acemoglu (1998) and Goldin and Katz (1998). Acemoglu's endogenous model of technological change predicts that an increase in unskilled to skilled labor endowment will lead to higher productivity of unskilled technology. As noted by Goldin and Katz (1998) and many others, the form of unskilled technology in manufacturing was embodied in the form of a factory system based on division of labor.

Based on the analysis of firm level data merged with county level information for the period between 1850 and 1880, I find that immigration had a significant impact on the shift in manufacturing from artisans to factories. Instrumental variable estimates indicate that firms in counties with a significantly higher share of foreign-born population were much more likely to organize as factories than as artisans. The diversity of immigrants also seem to have contributed to the rise of a factory system based on division of labor.

In the United States, the factory system of production arose in rural New England between 1820 and 1840 to take advantage of that region's abundance in unskilled native women and children. ${ }^{28}$ However, because the supply of native unskilled workers was limited and too homogenous, the industrial revolution in the Unites States would have been much more muted

\footnotetext{
28 Legal factors may have also lowered the costs of locating in rural locations during this period. Steinfeld (1991, 2001) argues that early American labor was "unfree" in the sense that employers possessed significant legal rights over workers. In particular, workers who breached their employment contracts were subject to criminal sanctions or forfeiture of back wages. Consequently, the employer's legal position reduced the level of turn-over in the labor market. In the 1850's, with the rise in the idea of "free labor" in America, employers lost much of their legal leverage over employees. As workers could terminate their employment any time, the change in the legal environment likely increased worker turn-over and raised the cost of recruiting workers in rural areas. Interestingly, Hamilton (2000) suggests that changes in the ability of a master to enforce apprentice contracts in North America
} 
without immigrants. Immigrants not only significantly increased the unskilled to skilled labor endowment, but they also increased the diversity of skills and worker attributes important for division of labor in factories. In addition, immigration and division of labor significantly contributed to urbanization (Kim (2006)).

What lessons and insights emerge from history for understanding the impact of immigration on the American economy today? The experience of the era of mass immigration points to the great absorptive capacity of the American economy. While immigration may lower the wages of natives in the short run, the long-run impact of immigration is likely to have been much more positive as indicated by the secular rise in long-run real wages (Figure 4). In this paper, I suggest that the source of this great absorptive capacity of the American economy lies in its ability to develop and implement technologies which favor changing factor endowment conditions. In addition, history teaches that these induced technological changes have had a major impact on the geographic landscape of the American economy.

may have contributed to the shift in manufacturing from artisans to factory production in the $1820 \mathrm{~s}$. 
Figure 1: Annual Immigration Flows, 1820-2000

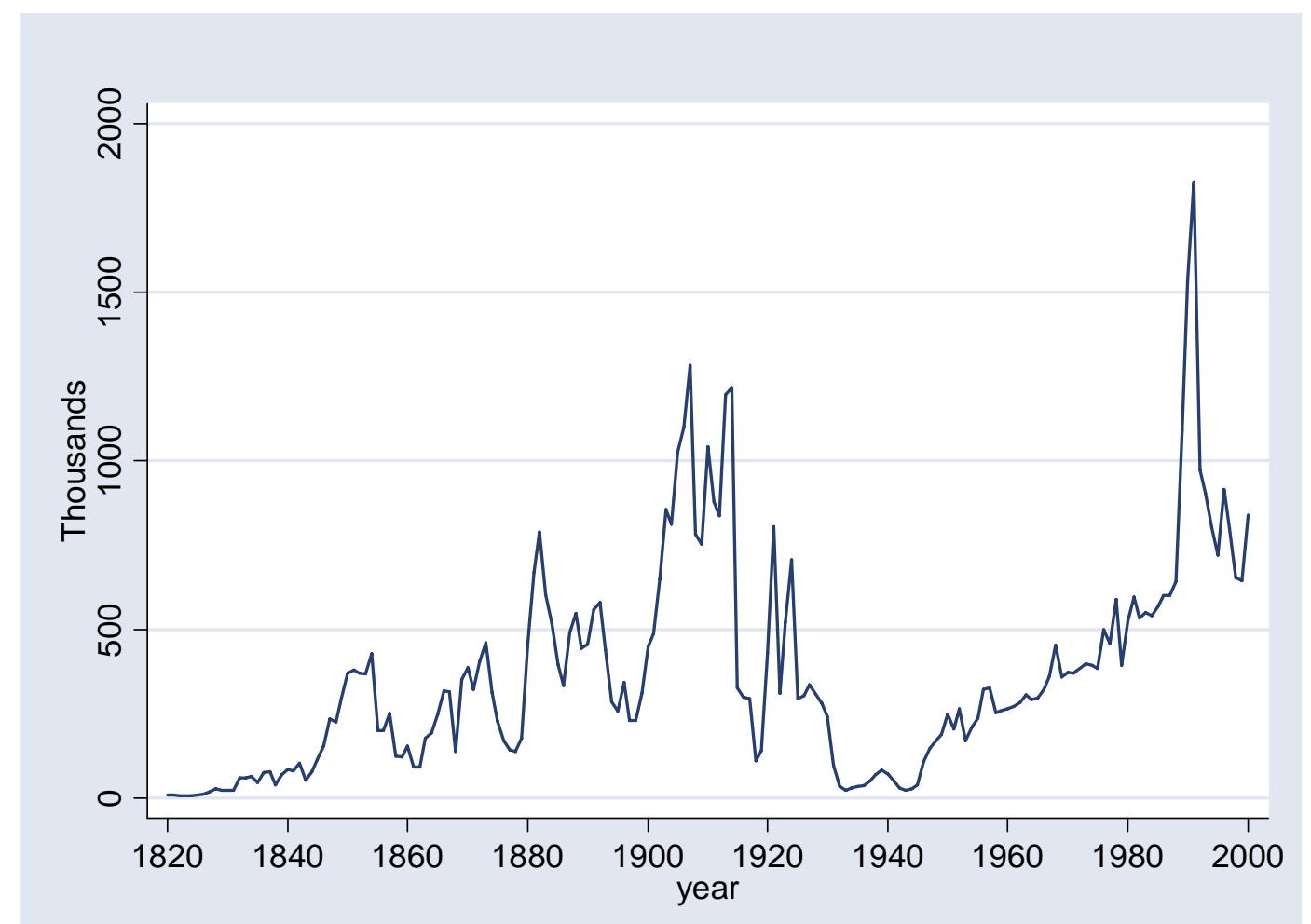

Sources: Historical Statistics of the U.S. and Statistical Abstract of the U.S. 
Figure 2: Foreign-Born and Foreign-Stock as Shares of Population, 1850-1990

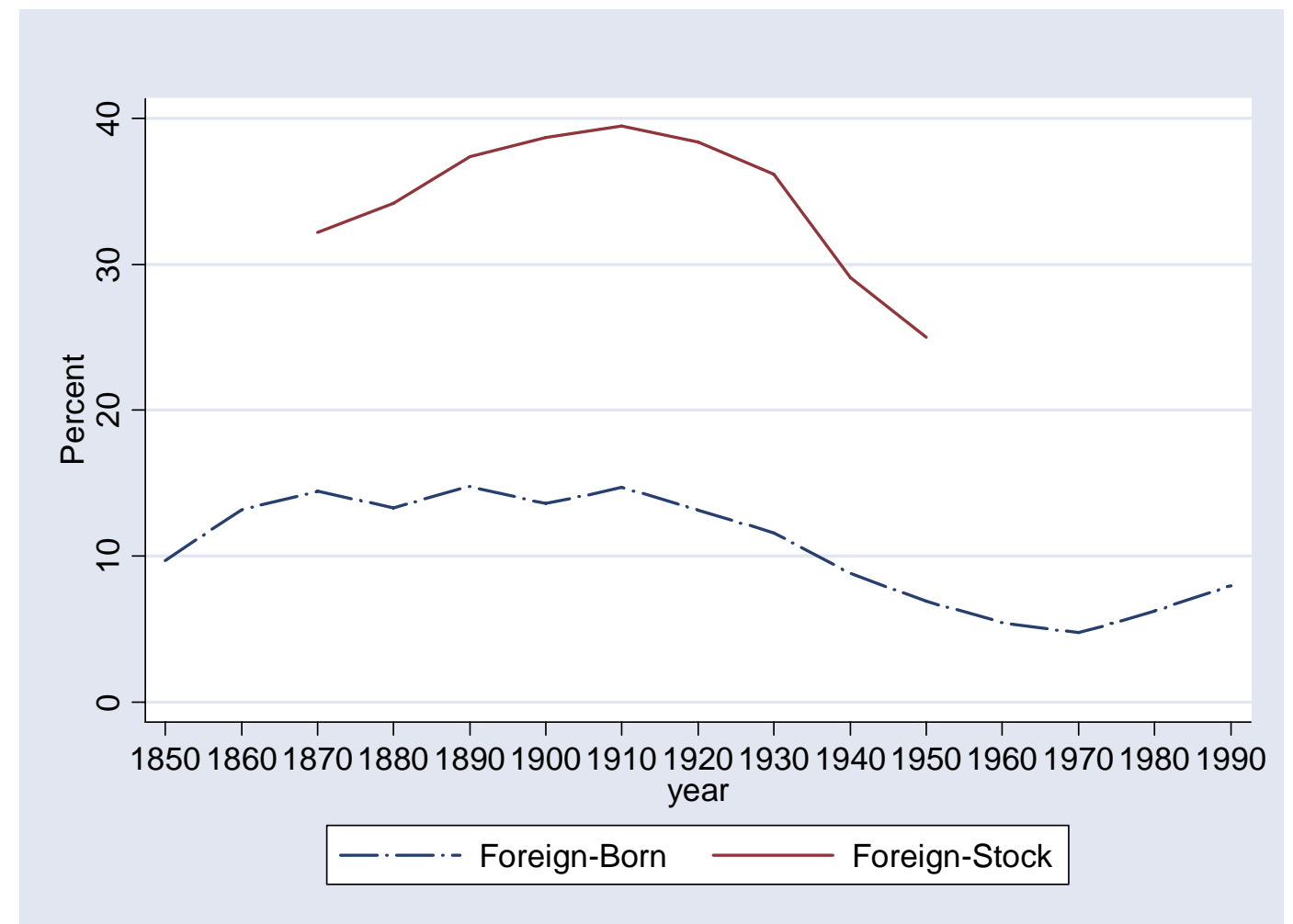

Note: Foreign-stock or immigrants and their children is measured as foreign-born plus the native born of foreign or mixed parentage. Foreign-stock is for only the white population. Sources: Gibson and Lennon (1999) and Hutchinson (1956). 
Figure 3: Annual Immigration as a Percentage of Population, 1820-2000

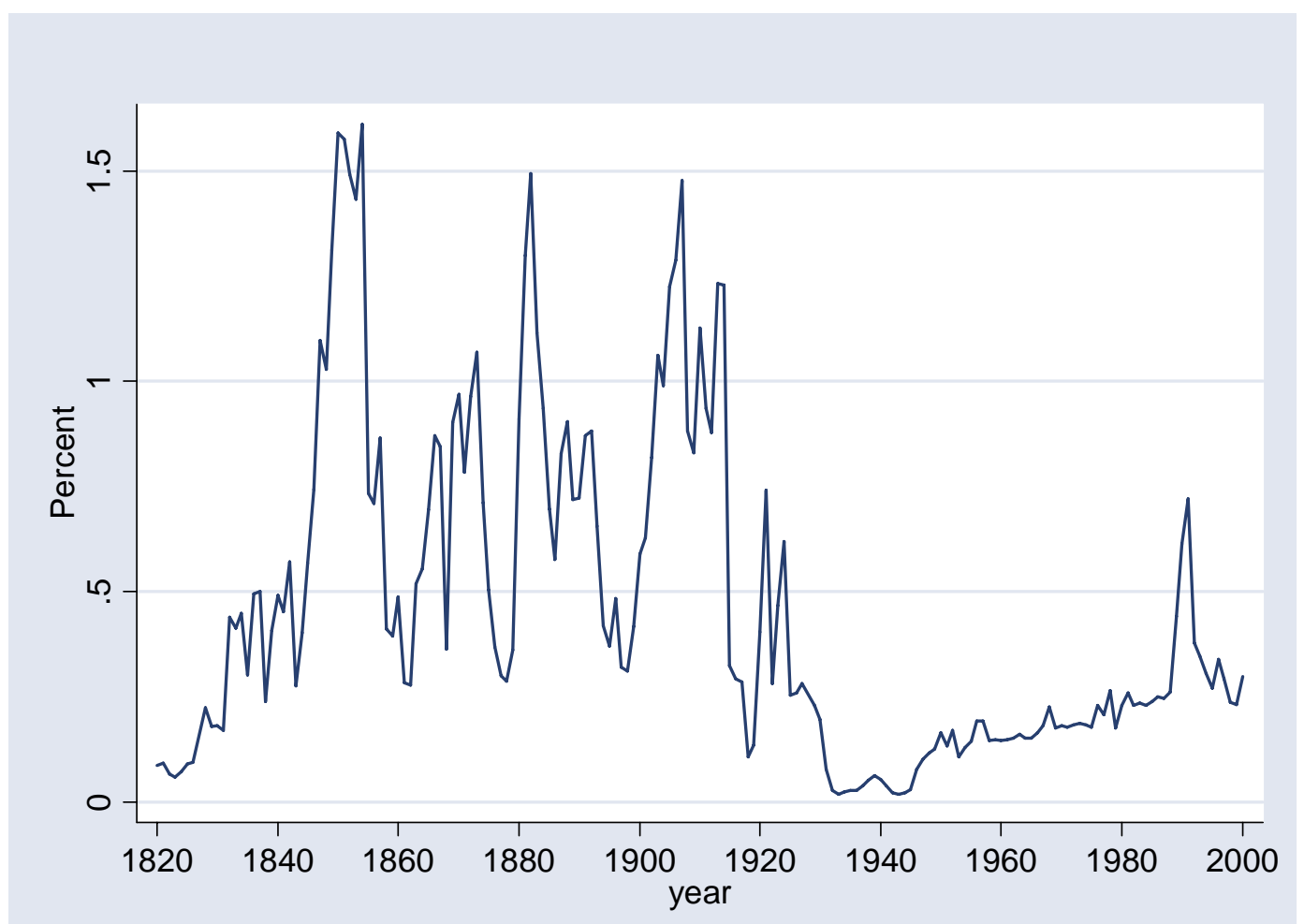

Sources: Historical Statistics of the U.S. and Statistical Abstract of the U.S. 
Figure 4: Real Annual Wages, 1820-1940

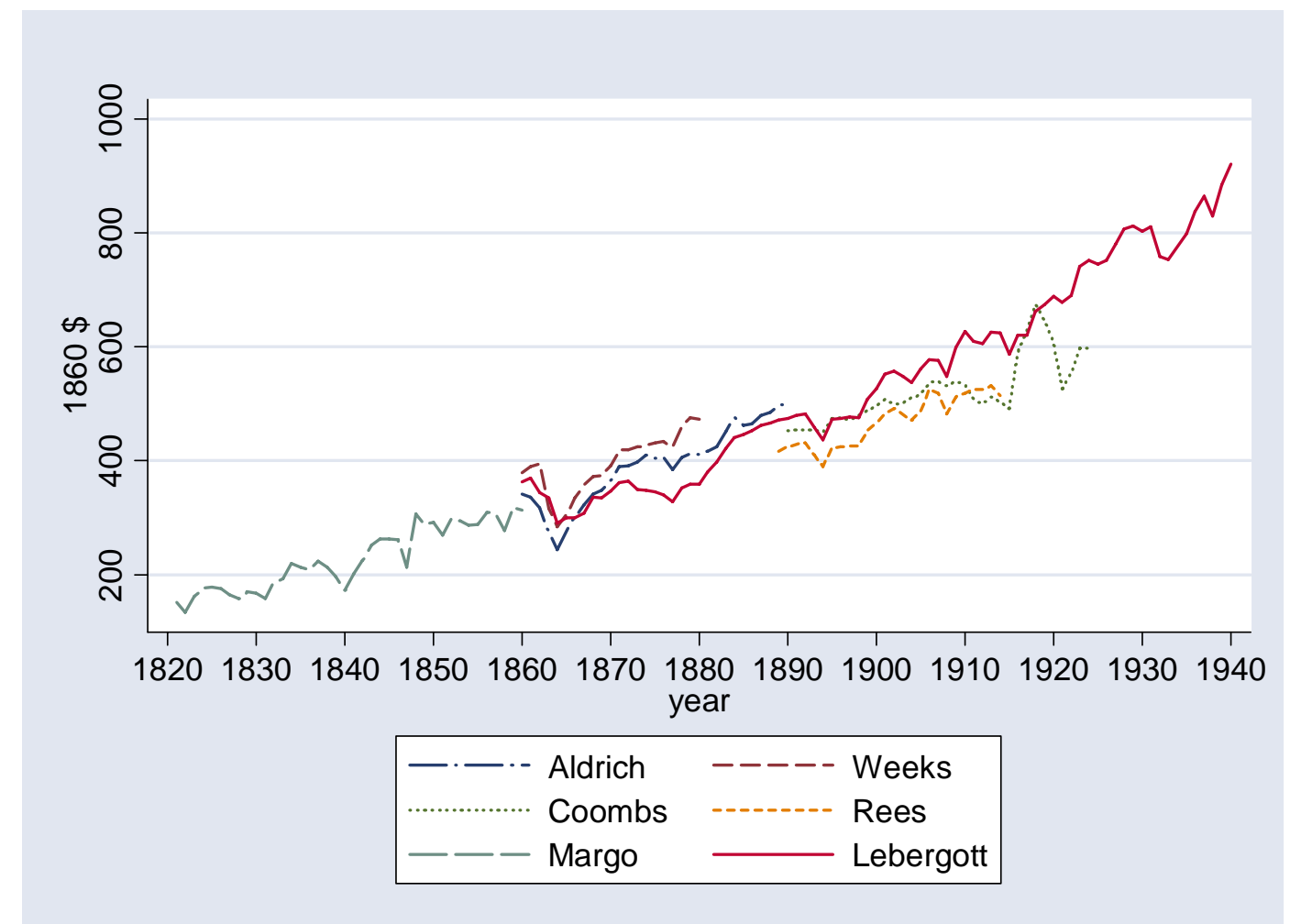

Note: Aldrich, Weeks, Rees and Lebergott series are average earnings in all manufacturing; Coombes series is the average earnings of unskilled workers in manufacturing. Sources: Coombes (1926), Long (1960), Rees (1961), Lebergott (1964), and Margo (2000). 
Table 1

Sources of Immigration, 1820-1930

\begin{tabular}{|c|c|c|c|c|c|c|c|}
\hline Years & $\begin{array}{l}\text { Average } \\
\text { Yearly } \\
\text { Total } \\
\text { (Per } 1000 \\
\text { Population) }\end{array}$ & $\begin{array}{l}\text { Great } \\
\text { Britain }\end{array}$ & Ireland & $\begin{array}{l}\text { Other } \\
\text { NW } \\
\text { Europe }\end{array}$ & Germany & $\begin{array}{l}\text { Central \& } \\
\text { Eastern } \\
\text { Europe }\end{array}$ & $\begin{array}{l}\text { Southern } \\
\text { Europe }\end{array}$ \\
\hline $1820-1831$ & $14,538(1.3)$ & $22 \%$ & $45 \%$ & $12 \%$ & $8 \%$ & $0 \%$ & $2 \%$ \\
\hline $1832-1846$ & $71,916(4.3)$ & 16 & 41 & 9 & 27 & 0 & 1 \\
\hline $1847-1854$ & $334,506(14.0)$ & 13 & 45 & 6 & 32 & 0 & 0 \\
\hline $1855-1964$ & $160,427(5.2)$ & 25 & 28 & 5 & 33 & 0 & 1 \\
\hline $1865-1873$ & $327,464(8.4)$ & 24 & 16 & 10 & 34 & 1 & 1 \\
\hline $1874-1880$ & $260,754(5.6)$ & 18 & 15 & 14 & 24 & 5 & 3 \\
\hline $1881-1893$ & $525,102(8.9)$ & 14 & 12 & 16 & 26 & 16 & 8 \\
\hline 1894-1899 & $276,547(3.9)$ & 7 & 12 & 12 & 11 & 32 & 22 \\
\hline $1900-1914$ & $891,806(10.2)$ & 6 & 4 & 7 & 4 & 45 & 26 \\
\hline 1915-1919 & $234,536(2.3)$ & 5 & 2 & 8 & 1 & 7 & 21 \\
\hline $1920-1930$ & $412,474(3.6)$ & 8 & 5 & 8 & 9 & 14 & 16 \\
\hline
\end{tabular}

Source: Cohn (2006).

Table 2

Occupation of Immigrants, 1820-1898

\begin{tabular}{lllllllll}
\hline & $1820-$ & $1832-$ & $1847-$ & $1855-$ & $1865-$ & $1874-$ & $1881-$ & $1894-$ \\
Occupation & 1831 & 1846 & 1854 & 1864 & 1873 & 1880 & 1893 & 1898 \\
& & & & & & & \\
\hline
\end{tabular}

Source: Cohn (2006). 
Table 3

Occupational Structure of English Immigrants, 1836-1853

\begin{tabular}{|c|c|c|c|c|}
\hline \multirow{2}{*}{$\begin{array}{l}\text { Occupation } \\
\text { Farmers }\end{array}$} & \multicolumn{2}{|c|}{$\begin{array}{l}1836-1845 \quad 1846-1853 \\
\text { (Percentage of total male immigrants) }\end{array}$} & \multicolumn{2}{|c|}{$\begin{array}{l}\text { 1836-1845 } 1846-1853 \\
\text { (Ratio of percentage in the immigrant } \\
\text { sample to the percentage of that group in } \\
\text { the English population) }\end{array}$} \\
\hline & $16.3 \%$ & $17.8 \%$ & 0.58 & 2.95 \\
\hline Laborers & 44.0 & 53.1 & 5.37 & 6.90 \\
\hline Servants & 2.9 & 1.7 & 0.32 & 0.27 \\
\hline Total Preindustrial & 28.0 & 20.4 & 0.94 & 0.72 \\
\hline Building trades & 4.5 & 2.7 & 0.56 & 0.46 \\
\hline Mining & 7.8 & 4.4 & 2.36 & 0.85 \\
\hline Food & 3.4 & 1.8 & 0.81 & 0.50 \\
\hline Metal & 1.8 & 1.9 & 0.62 & 0.86 \\
\hline Clothing & 5.0 & 4.8 & 0.68 & 0.77 \\
\hline Woodworking & 1.8 & 1.5 & 0.72 & 0.82 \\
\hline Miscellaneous & 0.3 & 0.7 & 0.20 & 0.35 \\
\hline Mechanics & 3.4 & 2.6 & - & - \\
\hline Total Industrial & 4.3 & 4.1 & 0.28 & 0.35 \\
\hline Textiles & 2.5 & 0.9 & 0.30 & 0.18 \\
\hline Iron and Steel & 0.8 & 2.2 & 0.16 & 0.54 \\
\hline Miscellaneous & 1.1 & 1.0 & 0.55 & 0.65 \\
\hline Total Tertiary & 4.4 & 2.9 & 0.45 & 0.31 \\
\hline Clerical & 0.6 & 1.1 & 0.27 & 0.57 \\
\hline Commercial & 2.7 & 1.2 & 0.55 & 0.22 \\
\hline Professional & 1.1 & 0.5 & 0.44 & 0.32 \\
\hline Number of Males & 925 & 1481 & 925 & 1481 \\
\hline
\end{tabular}

Note: The information is based on samples randomly drawn from the passenger lists of ships which arrived in New York City between 1836 and 1853 .

Source: Cohn (1992). 
Table 4

U.S. County Population Characteristics by Region, 1850-1880

\begin{tabular}{|c|c|c|c|c|}
\hline Counties & 1850 & 1860 & 1870 & 1880 \\
\hline \multicolumn{5}{|l|}{ U.S. Total } \\
\hline Number of Counties & 1623 & 2079 & 2291 & 2613 \\
\hline Population & 14290 & 15122 & 16830 & 19208 \\
\hline Urban (\%) & 3.8 & 4.7 & 7.5 & 8.1 \\
\hline Foreign Born (\%) & 5.9 & 9.6 & 11.5 & 10.7 \\
\hline Native Born Out of State $(\%)$ & 29.4 & - & 33.0 & 31.6 \\
\hline Mfg Labor (\%) & 1.8 & 2.2 & 2.4 & 1.9 \\
\hline \multicolumn{5}{|l|}{ New England } \\
\hline Number of Counties & 64 & 67 & 67 & 67 \\
\hline Population & 42627 & 46795 & 52059 & 59859 \\
\hline Urban (\%) & 18.4 & 22.1 & 26.2 & 30.6 \\
\hline Foreign Born $(\%)$ & 9.2 & 11.0 & 13.6 & 14.2 \\
\hline Native Born Out of State $(\%)$ & 13.5 & - & 12.9 & 13.7 \\
\hline Mfg Labor (\%) & 7.7 & 9.1 & 11.2 & 11.6 \\
\hline \multicolumn{5}{|l|}{ Middle Atlantic } \\
\hline Number of Counties & 142 & 146 & 147 & 148 \\
\hline Population & 41540 & 51089 & 59937 & 70924 \\
\hline Urban (\%) & 8.4 & 12.8 & 20.2 & 24.2 \\
\hline Foreign Born (\%) & 11.1 & 13.0 & 13.5 & 11.9 \\
\hline Native Born Out of State $(\%)$ & 10.9 & - & 9.7 & 9.0 \\
\hline Mfg Labor (\%) & 4.5 & 4.6 & 6.0 & 6.1 \\
\hline \multicolumn{5}{|l|}{ East North Central } \\
\hline Number of Counties & 351 & 402 & 411 & 423 \\
\hline Population & 12887 & 17231 & 22201 & 26493 \\
\hline Urban (\%) & 3.5 & 5.9 & 14.4 & 14.1 \\
\hline Foreign Born $(\%)$ & 11.1 & 16.2 & 17.1 & 15.7 \\
\hline Native Born Out of State (\%) & 48.3 & - & 34.4 & 26.7 \\
\hline Mfg Labor (\%) & 1.8 & 2.5 & 3.4 & 3.0 \\
\hline \multicolumn{5}{|l|}{ West North Central } \\
\hline Number of Counties & 158 & 350 & 419 & 562 \\
\hline Population & 5572 & 6186 & 9204 & 10956 \\
\hline Urban (\%) & 1.3 & 2.3 & 4.8 & 5.6 \\
\hline Foreign Born $(\%)$ & 6.4 & 14.7 & 19.7 & 18.0 \\
\hline Native Born Out of State (\%) & 56.7 & - & 62.0 & 58.7 \\
\hline Mfg Labor (\%) & 0.9 & 1.2 & 1.4 & 1.0 \\
\hline \multicolumn{5}{|l|}{ South Atlantic } \\
\hline Number of Counties & 394 & 459 & 470 & 484 \\
\hline Population & 11876 & 11688 & 12454 & 15697 \\
\hline Urban $(\%)$ & 3.1 & 3.5 & 3.7 & 4.6 \\
\hline Foreign Born (\%) & 1.4 & 1.4 & 1.1 & 1.0 \\
\hline Native Born Out of State (\%) & 8.5 & - & 10.0 & 11.4 \\
\hline Mfg Labor (\%) & 1.3 & 1.5 & 1.4 & 1.5 \\
\hline
\end{tabular}


Table 4 - continued

U.S. County Population Characteristics by Region, 1850-1880

\begin{tabular}{|c|c|c|c|c|}
\hline Counties & 1850 & 1860 & 1870 & 1880 \\
\hline \multicolumn{5}{|l|}{ East South Central } \\
\hline Number of Counties & 290 & 305 & 330 & 351 \\
\hline Population & 11597 & 13184 & 13347 & 15912 \\
\hline Urban (\%) & 1.7 & 2.3 & 3.2 & 3.0 \\
\hline Foreign Born (\%) & 1.0 & 1.6 & 1.3 & 1.0 \\
\hline Native Born Out of State (\%) & 20.1 & - & 19.4 & 15.3 \\
\hline Mfg Labor (\%) & 1.1 & 1.1 & 1.1 & 0.9 \\
\hline \multicolumn{5}{|l|}{ West South Central } \\
\hline Number of Counties & 176 & 236 & 255 & 357 \\
\hline Population & 5342 & 7405 & 7961 & 9340 \\
\hline Urban (\%) & 2.8 & 2.1 & 2.4 & 3.1 \\
\hline Foreign Born (\%) & 5.6 & 6.9 & 6.7 & 6.0 \\
\hline Native Born Out of State (\%) & 40.1 & - & 41.8 & 38.7 \\
\hline Mfg Labor (\%) & 0.5 & 0.7 & 1.5 & 0.5 \\
\hline \multicolumn{5}{|l|}{ Mountain } \\
\hline Number of Counties & 14 & 32 & 98 & 119 \\
\hline Population & 5209 & 5466 & 3218 & 5488 \\
\hline Urban (\%) & 4.2 & 4.5 & 5.9 & 8.0 \\
\hline Foreign Born (\%) & 9.6 & 22.4 & 31.2 & 25.5 \\
\hline Native Born Out of State (\%) & 44.2 & - & 63.6 & 58.8 \\
\hline Mfg Labor (\%) & 0.2 & 1.4 & 2.6 & 1.0 \\
\hline \multicolumn{5}{|l|}{ Pacific } \\
\hline Number of Counties & 34 & 82 & 94 & 102 \\
\hline Population & 3114 & 5415 & 7182 & 11255 \\
\hline Urban $(\%)$ & 2.2 & 3.7 & 5.0 & 8.3 \\
\hline Foreign Born (\%) & 16.1 & 26.1 & 26.2 & 25.2 \\
\hline Native Born Out of State (\%) & 73.3 & - & 56.2 & 50.0 \\
\hline Mfg Labor (\%) & 3.6 & 4.9 & 3.3 & 1.9 \\
\hline
\end{tabular}

Source: ICPSR Study Number 2896 (Michael Haines) 
Table 5

Summary Statistics, 1850-1880:

Mean (Standard Deviation)

\begin{tabular}{lllll}
\hline All Firms & 1850 & 1860 & 1870 & 1880 \\
\hline Factory & $0.10(0.295)$ & $0.10(0.298)$ & $0.14(0.350)$ & $0.16(0.364)$ \\
Firm size (log) & $1.56(0.863)$ & $1.56(0.897)$ & $1.71(1.016)$ & $1.75(1.019)$ \\
Annual wage (log) & $5.20(0.499)$ & $5.34(0.483)$ & $5.47(0.692)$ & $5.23(0.743)$ \\
Labor productivity (log) & $5.81(0.843)$ & $6.02(0.870)$ & $6.33(0.868)$ & $6.11(0.806)$ \\
& & & & \\
Foreign-born (\%) & $0.13(0.134)$ & $0.15(0.140)$ & $0.17(0.145)$ & $0.16(0.126)$ \\
K/L ratio (log) & $5.60(1.148)$ & $5.97(1.099)$ & $6.15(1.175)$ & $5.99(1.147)$ \\
Share of male labor & $0.68(0.169)$ & $0.68(0.172)$ & $0.68(0.199)$ & $0.69(0.192)$ \\
Steam power & $0.08(0.272)$ & $0.17(0.378)$ & $0.26(0.438)$ & $0.25(0.436)$ \\
Water power & $0.30(0.458)$ & $0.26(0.437)$ & $0.18(0.386)$ & $0.16(0.365)$ \\
Number of firms & 6,868 & 7,446 & 5,327 & 8,658 \\
\hline Counties & 1850 & 1860 & 1870 & 1880 \\
\hline Foreign-born (\%) & $0.059(0.101)$ & $0.096(0.133)$ & $0.115(0.152)$ & $0.107(0.132)$ \\
Number of Counties & 1618 & 2079 & 2290 & 2569 \\
\hline
\end{tabular}

Note: Factory is equal to 1 if a firm employed more than 15 workers and 0 otherwise. Firm size is defined as one plus number of male, female, and child workers. Steam power is equal to 1 if a firm used steam and 0 otherwise; same for water power. Sample selection criteria was same as that of Atack, Bateman and Margo (2004): Gross output greater than $\$ 500$; for 1850 and 1860 , average monthly wage greater than $\$ 4.76$ but less than $\$ 190.5$; and, for 1870 and 1880 , average monthly wage greater than $\$ 5.20$ but less than $\$ 208$. For source notes, see Atack and Bateman (1999). 
Table 6

First Stage Regressions

\begin{tabular}{|c|c|c|c|c|c|c|c|c|c|c|c|c|}
\hline Foreign-born (ratio) & $\begin{array}{l}1860 \\
(1)\end{array}$ & $\begin{array}{l}1860 \\
(2)\end{array}$ & $\begin{array}{l}1860 \\
(3)\end{array}$ & $\begin{array}{l}1860 \\
(4)\end{array}$ & $\begin{array}{l}1870 \\
(1)\end{array}$ & $\begin{array}{l}1870 \\
(2)\end{array}$ & $\begin{array}{l}1870 \\
(3)\end{array}$ & $\begin{array}{l}1870 \\
(4)\end{array}$ & $\begin{array}{l}1880 \\
(1)\end{array}$ & $\begin{array}{l}1880 \\
(2)\end{array}$ & $\begin{array}{l}1880 \\
(3)\end{array}$ & $\begin{array}{l}1880 \\
(4)\end{array}$ \\
\hline $\begin{array}{l}1850 \text { Foreign-born } \\
\text { population ratio }\end{array}$ & $\begin{array}{l}0.91 * \\
(224.6)\end{array}$ & - & $\begin{array}{l}0.90^{*} \\
(220.1)\end{array}$ & - & $\begin{array}{l}0.74 * \\
(155.9)\end{array}$ & - & $\begin{array}{l}0.73 * \\
(149.0)\end{array}$ & - & $\begin{array}{l}0.62 * \\
(147.8)\end{array}$ & - & $\begin{array}{l}0.61 * \\
(147.4)\end{array}$ & - \\
\hline $\begin{array}{l}\text { Growth in Foreign-born } \\
(1860-1850)\end{array}$ & - & $\begin{array}{l}0.04 * \\
(17.3)\end{array}$ & $\begin{array}{l}0.005^{*} \\
(5.90)\end{array}$ & - & - & $\begin{array}{l}0.05^{*} \\
(21.7)\end{array}$ & $\begin{array}{l}0.01 * \\
(10.6)\end{array}$ & - & - & $\begin{array}{l}0.01^{*} \\
(12.7)\end{array}$ & $\begin{array}{l}0.006^{*} \\
(12.7)\end{array}$ & - \\
\hline Log (Distance) & - & - & - & $\begin{array}{l}-0.06^{*} \\
(34.2)\end{array}$ & - & - & - & $\begin{array}{l}-0.03 * \\
(4.97)\end{array}$ & - & - & - & $\begin{array}{l}-0.04 * \\
(33.6)\end{array}$ \\
\hline $\begin{array}{l}\text { Access to water } \\
\text { transportation in } \\
1850\end{array}$ & - & - & - & $\begin{array}{l}0.06^{*} \\
(21.1)\end{array}$ & - & - & - & $\begin{array}{l}0.03 * \\
(8.45)\end{array}$ & - & - & - & $\begin{array}{l}0.05 * \\
(23.2)\end{array}$ \\
\hline $\begin{array}{l}\text { Staiger and Watson } \\
\text { F-statistics }\end{array}$ & 50492 & 298 & 25456 & 819 & 24292 & 473 & 12502 & 691 & 21836 & 162 & 11201 & 844 \\
\hline $\begin{array}{l}\text { R-squared } \\
\text { Observations }\end{array}$ & $\begin{array}{l}0.94 \\
6695\end{array}$ & $\begin{array}{l}0.54 \\
6726\end{array}$ & $\begin{array}{l}0.94 \\
6727\end{array}$ & $\begin{array}{l}0.51 \\
6727\end{array}$ & $\begin{array}{l}0.86 \\
4600\end{array}$ & $\begin{array}{l}0.59 \\
4600\end{array}$ & $\begin{array}{l}0.93 \\
4600\end{array}$ & $\begin{array}{l}0.59 \\
4654\end{array}$ & $\begin{array}{l}0.90 \\
6868\end{array}$ & $\begin{array}{l}0.59 \\
6868\end{array}$ & $\begin{array}{l}0.90 \\
6868\end{array}$ & $\begin{array}{l}0.68 \\
6973\end{array}$ \\
\hline
\end{tabular}

Note: $t$-statistics in parentheses. * Significant at the $5 \%$ level.

Regressions include all the exogenous variables including state and 3-digit industry fixed-effects.

Growth in foreign-born is defined as (Foreign-born 1860 - Foreign-born 1850$) /$ Population $_{1850}$.

Distance measures square miles from Kings County, New York and is constructed using data on county longitude and latitude from

http://www.census.gov/tiger/tms/gazetteer. Distance between two points, A and B, is calculated using the following approximate formula: [(69.1*(longitudeA-

longitudeB $\left.))^{2}+(53.0 *(\text { latitudeA-latitudeB }))^{2}\right]^{1 / 2}$. 
Table 7

Determinants of Factory Organization, Firm Size, Wages and Labor Productivity in U.S. Manufacturing, 1860-1880

\begin{tabular}{|c|c|c|c|c|c|c|c|c|c|c|c|c|}
\hline & \multicolumn{3}{|c|}{ Factory } & \multicolumn{3}{|c|}{ Firm Size (log) } & \multicolumn{3}{|c|}{ Wages (log) } & \multicolumn{3}{|c|}{ Labor Productivity (log) } \\
\hline & Probit & Probit & Probit & OLS & OLS & OLS & OLS & OLS & OLS & OLS & OLS & OLS \\
\hline & 1860 & 1870 & 1880 & 1860 & 1870 & 1880 & 1860 & 1870 & 1880 & 1860 & 1870 & 1880 \\
\hline Fgn-born (\%) & $\begin{array}{l}2.23 * \\
(8.30)\end{array}$ & $\begin{array}{l}2.56^{*} \\
(9.21)\end{array}$ & $\begin{array}{l}2.00 * \\
(8.29)\end{array}$ & $\begin{array}{l}0.78^{*} \\
(6.20)\end{array}$ & $\begin{array}{l}1.15^{*} \\
(11.1)\end{array}$ & $\begin{array}{l}1.11^{*} \\
(11.1)\end{array}$ & $\begin{array}{l}0.56^{*} \\
(14.0)\end{array}$ & $\begin{array}{l}1.31 * \\
(17.0)\end{array}$ & $\begin{array}{l}1.54 * \\
(20.0)\end{array}$ & $\begin{array}{l}0.93 * \\
(10.3)\end{array}$ & $\begin{array}{l}1.16^{*} \\
(10.7)\end{array}$ & $\begin{array}{l}1.48 * \\
(16.4)\end{array}$ \\
\hline $\operatorname{Ln}(\mathrm{K} / \mathrm{L})$ & $\begin{array}{l}0.06^{*} \\
(2.16)\end{array}$ & $\begin{array}{l}0.08 * \\
(2.91)\end{array}$ & $\begin{array}{l}0.10 * \\
(4.53)\end{array}$ & $\begin{array}{l}0.04 * \\
(3.25)\end{array}$ & $\begin{array}{l}0.04 * \\
(3.57)\end{array}$ & $\begin{array}{l}0.03 * \\
(3.13)\end{array}$ & $\begin{array}{l}0.07 * \\
(14.4)\end{array}$ & $\begin{array}{l}0.20 * \\
(26.3)\end{array}$ & $\begin{array}{l}0.20^{*} \\
(30.0)\end{array}$ & $\begin{array}{l}0.25 * \\
(24.5)\end{array}$ & $\begin{array}{l}0.27 * \\
(24.8)\end{array}$ & $\begin{array}{l}0.27 * \\
(35.0)\end{array}$ \\
\hline $\mathrm{Men} / \mathrm{L}$ & $\begin{array}{l}2.40 * \\
(13.8)\end{array}$ & $\begin{array}{l}1.77 * \\
(11.2)\end{array}$ & $\begin{array}{l}1.78 * \\
(15.1)\end{array}$ & $\begin{array}{l}2.62 * \\
(13.8)\end{array}$ & $\begin{array}{l}1.99 * \\
(33.1)\end{array}$ & $\begin{array}{l}1.97 * \\
(39.5)\end{array}$ & $\begin{array}{l}1.16^{*} \\
(42.0)\end{array}$ & $\begin{array}{l}0.85^{*} \\
(19.2)\end{array}$ & $\begin{array}{l}1.06^{*} \\
(27.9)\end{array}$ & $\begin{array}{l}1.06^{*} \\
(16.9)\end{array}$ & $\begin{array}{l}0.39 * \\
(6.19)\end{array}$ & $\begin{array}{l}0.43 * \\
(9.56)\end{array}$ \\
\hline Steam & $\begin{array}{l}0.91 * \\
(10.7)\end{array}$ & $\begin{array}{l}1.12 * \\
(14.0)\end{array}$ & $\begin{array}{l}1.21 * \\
(21.8)\end{array}$ & $\begin{array}{l}0.43 * \\
(8.40)\end{array}$ & $\begin{array}{l}0.71 * \\
(20.8)\end{array}$ & $\begin{array}{l}0.91 * \\
(34.5)\end{array}$ & $\begin{array}{l}0.02 \\
(1.74)\end{array}$ & $\begin{array}{l}0.07 * \\
(2.68)\end{array}$ & $\begin{array}{l}0.03 \\
(1.25)\end{array}$ & $\begin{array}{l}0.14 * \\
(4.31)\end{array}$ & $\begin{array}{l}0.16^{*} \\
(4.47)\end{array}$ & $\begin{array}{l}-0.01 \\
(0.31)\end{array}$ \\
\hline Water & $\begin{array}{l}0.12 \\
(1.19)\end{array}$ & $\begin{array}{l}0.49 * \\
(4.41)\end{array}$ & $\begin{array}{l}0.39 * \\
(4.38)\end{array}$ & $\begin{array}{l}0.06^{*} \\
(2.26)\end{array}$ & $\begin{array}{l}0.26^{*} \\
(6.31)\end{array}$ & $\begin{array}{l}0.37 * \\
(10.8)\end{array}$ & $\begin{array}{l}-0.07 * \\
(4.09)\end{array}$ & $\begin{array}{l}-0.13^{*} \\
(4.34)\end{array}$ & $\begin{array}{l}-0.14^{*} \\
(5.28)\end{array}$ & $\begin{array}{l}0.02 \\
(0.53)\end{array}$ & $\begin{array}{l}0.16^{*} \\
(4.47)\end{array}$ & $\begin{array}{l}-0.12 * \\
(3.83)\end{array}$ \\
\hline Constant & $\begin{array}{l}-3.87^{*} \\
(4.43)\end{array}$ & $\begin{array}{l}-3.29 * \\
(3.47)\end{array}$ & $\begin{array}{l}-2.60 * \\
(2.45)\end{array}$ & $\begin{array}{l}-0.51^{*} \\
(2.42)\end{array}$ & $\begin{array}{l}-0.83 \\
(1.12)\end{array}$ & $\begin{array}{l}2.33^{*} \\
(3.10)\end{array}$ & $\begin{array}{l}4.22 * \\
(12.7)\end{array}$ & $\begin{array}{l}2.41 * \\
(4.36)\end{array}$ & $\begin{array}{l}3.29 * \\
(5.74)\end{array}$ & $\begin{array}{l}6.65^{*} \\
(8.98)\end{array}$ & $\begin{array}{l}2.91 * \\
(3.77)\end{array}$ & $\begin{array}{l}3.87 * \\
(5.76)\end{array}$ \\
\hline $\begin{array}{l}\text { Fixed-effects } \\
\text { Industry } \\
\text { State }\end{array}$ & $\begin{array}{l}\text { yes } \\
\text { yes }\end{array}$ & $\begin{array}{l}\text { yes } \\
\text { yes }\end{array}$ & $\begin{array}{l}\text { yes } \\
\text { yes }\end{array}$ & $\begin{array}{l}\text { yes } \\
\text { yes }\end{array}$ & $\begin{array}{l}\text { yes } \\
\text { yes }\end{array}$ & $\begin{array}{l}\text { yes } \\
\text { yes }\end{array}$ & $\begin{array}{l}\text { yes } \\
\text { yes }\end{array}$ & $\begin{array}{l}\text { yes } \\
\text { yes }\end{array}$ & $\begin{array}{l}\text { yes } \\
\text { yes }\end{array}$ & $\begin{array}{l}\text { yes } \\
\text { yes }\end{array}$ & $\begin{array}{l}\text { yes } \\
\text { yes }\end{array}$ & $\begin{array}{l}\text { yes } \\
\text { yes }\end{array}$ \\
\hline $\begin{array}{l}\text { Pseudo or } \\
\text { R-squared }\end{array}$ & 0.37 & 0.33 & 0.32 & 0.55 & 0.51 & 0.47 & 0.55 & 0.42 & 0.43 & 0.31 & 0.27 & 0.33 \\
\hline Observations & 7323 & 5198 & 8603 & 7385 & 5288 & 8658 & 7385 & 5288 & 8658 & 7258 & 5165 & 8632 \\
\hline
\end{tabular}

Note: $z$-statistics in parentheses. * Significant at the $5 \%$ level.

Factory is equal to 1 if a firm employed more than 15 workers and 0 otherwise. 
Table 8

Ethnic Diversity and Factories, 1870-1880

\begin{tabular}{|c|c|c|c|c|c|c|c|c|}
\hline & \multicolumn{2}{|c|}{ Factories } & \multicolumn{2}{|c|}{ Firm Size $(\log )$} & \multicolumn{2}{|c|}{ Wages $(\log )$} & \multicolumn{2}{|c|}{ Labor Productivity $(\log )$} \\
\hline & $\begin{array}{l}\text { Probit } \\
1870\end{array}$ & $\begin{array}{l}\text { Probit } \\
1880\end{array}$ & $\begin{array}{l}\text { OLS } \\
1870\end{array}$ & $\begin{array}{l}\text { OLS } \\
1880\end{array}$ & $\begin{array}{l}\text { OLS } \\
1870\end{array}$ & $\begin{array}{l}\text { OLS } \\
1880\end{array}$ & $\begin{array}{l}\text { OLS } \\
1870\end{array}$ & $\begin{array}{l}\text { OLS } \\
1880\end{array}$ \\
\hline $\begin{array}{l}\text { Native Born } \\
\text { Out of State }\end{array}$ & $\begin{array}{l}0.49 \\
(1.13)\end{array}$ & $\begin{array}{l}0.06 \\
(0.16)\end{array}$ & $\begin{array}{l}0.10 \\
(0.72)\end{array}$ & $\begin{array}{l}-0.03 \\
(0.22)\end{array}$ & $\begin{array}{l}0.48^{*} \\
(4.42)\end{array}$ & $\begin{array}{l}0.47^{*} \\
(4.74)\end{array}$ & $\begin{array}{l}0.58^{*} \\
(3.75)\end{array}$ & $\begin{array}{l}0.60^{*} \\
(5.19)\end{array}$ \\
\hline $\begin{array}{l}\text { English \& } \\
\text { Wales }\end{array}$ & $\begin{array}{l}1.53 \\
(0.66)\end{array}$ & $\begin{array}{l}4.90^{*} \\
(2.39)\end{array}$ & $\begin{array}{l}0.14 \\
(0.16)\end{array}$ & $\begin{array}{l}1.94^{*} \\
(2.26)\end{array}$ & $\begin{array}{l}1.46^{*} \\
(2.31)\end{array}$ & $\begin{array}{l}2.68^{*} \\
(4.14)\end{array}$ & $\begin{array}{l}0.68 \\
(0.75)\end{array}$ & $\begin{array}{l}2.11^{*} \\
(2.78)\end{array}$ \\
\hline $\begin{array}{l}\text { British } \\
\text { America }\end{array}$ & $\begin{array}{l}5.26^{*} \\
(4.19)\end{array}$ & $\begin{array}{l}3.25^{*} \\
(3.44)\end{array}$ & $\begin{array}{l}1.07 * \\
(2.40)\end{array}$ & $\begin{array}{l}1.03^{*} \\
(2.56)\end{array}$ & $\begin{array}{l}0.53 \\
(1.60)\end{array}$ & $\begin{array}{l}1.18^{*} \\
(3.90)\end{array}$ & $\begin{array}{l}-0.40 \\
(0.86)\end{array}$ & $\begin{array}{l}1.16^{*} \\
(3.27)\end{array}$ \\
\hline Ireland & $\begin{array}{l}4.80^{*} \\
(4.25)\end{array}$ & $\begin{array}{l}3.43^{*} \\
(3.10)\end{array}$ & $\begin{array}{l}2.49^{*} \\
(6.12)\end{array}$ & $\begin{array}{l}2.15^{*} \\
(4.65)\end{array}$ & $\begin{array}{l}2.15^{*} \\
(7.17)\end{array}$ & $\begin{array}{l}3.15^{*} \\
(9.08)\end{array}$ & $\begin{array}{l}1.88^{*} \\
(4.41)\end{array}$ & $\begin{array}{l}2.75^{*} \\
(6.73)\end{array}$ \\
\hline Germany & $\begin{array}{l}6.68^{*} \\
(6.81)\end{array}$ & $\begin{array}{l}3.51^{*} \\
(4.32)\end{array}$ & $\begin{array}{l}1.62 * \\
(4.85)\end{array}$ & $\begin{array}{l}1.26^{*} \\
(3.79)\end{array}$ & $\begin{array}{l}1.51^{*} \\
(6.11)\end{array}$ & $\begin{array}{l}2.45^{*} \\
(9.79)\end{array}$ & $\begin{array}{l}0.67 \\
(1.93)\end{array}$ & $\begin{array}{l}2.31^{*} \\
(7.85)\end{array}$ \\
\hline Italy & $\begin{array}{l}-0.97 \\
(0.07)\end{array}$ & $\begin{array}{l}-29.4^{*} \\
(2.12)\end{array}$ & $\begin{array}{l}-3.20 \\
(0.67)\end{array}$ & $\begin{array}{l}-23.1^{*} \\
(3.72)\end{array}$ & $\begin{array}{l}-8.97^{*} \\
(2.56)\end{array}$ & $\begin{array}{l}18.5^{*} \\
(3.98)\end{array}$ & $\begin{array}{l}-7.71 \\
(1.51)\end{array}$ & $\begin{array}{l}22.9^{*} \\
(4.19)\end{array}$ \\
\hline Scandinavia & $\begin{array}{l}4.96^{*} \\
(2.86)\end{array}$ & $\begin{array}{l}4.72 * \\
(4.10)\end{array}$ & $\begin{array}{l}1.03 \\
(1.94)\end{array}$ & $\begin{array}{l}1.59^{*} \\
(3.48)\end{array}$ & $\begin{array}{l}1.18^{*} \\
(3.03)\end{array}$ & $\begin{array}{l}1.72 * \\
(5.01)\end{array}$ & $\begin{array}{l}-0.20 \\
(0.37)\end{array}$ & $\begin{array}{l}1.26^{*} \\
(3.11)\end{array}$ \\
\hline Diversity & $\begin{array}{l}12.2^{*} \\
(4.08)\end{array}$ & $\begin{array}{l}4.67 \\
(1.77)\end{array}$ & $\begin{array}{l}2.06^{*} \\
(2.15)\end{array}$ & $\begin{array}{l}0.66 \\
(0.57)\end{array}$ & $\begin{array}{l}0.43 \\
(0.60)\end{array}$ & $\begin{array}{l}4.31 * \\
(4.97)\end{array}$ & $\begin{array}{l}-2.54^{*} \\
(2.54)\end{array}$ & $\begin{array}{l}3.04^{*} \\
(2.98)\end{array}$ \\
\hline
\end{tabular}

Note: t-statistics in parentheses. * Significant at the 5\% level.

The regressions include all the other explanatory variables as in Table 7 except that the foreign-born variable has been replaced by shares of population of native born out of state and shares of foreign-born populations born of various European nations. 
Table 9

IV Estimation of Factory Organization of U.S. Manufacturing, 1860-1880

\begin{tabular}{|c|c|c|c|c|c|}
\hline 1860 & Probit & IV Probit \#1 & IV Probit \#2 & IV Probit \#3 & IV Probit \#4 \\
\hline Fgn-born (\%) & $\begin{array}{l}2.23^{*} \\
(8.30)\end{array}$ & $\begin{array}{l}2.15^{*} \\
(3.11)\end{array}$ & $\begin{array}{l}0.32 \\
(0.20)\end{array}$ & $\begin{array}{l}2.14^{*} \\
(7.09)\end{array}$ & $\begin{array}{l}2.71^{*} \\
(4.82)\end{array}$ \\
\hline $\begin{array}{l}\text { Wald test of } \\
\text { Exogeneity, } p>\text { chi }^{2}\end{array}$ & - & 0.14 & 0.21 & 0.12 & 0.42 \\
\hline 1870 & Probit & IV Probit \#1 & IV Probit \#2 & IV Probit \#3 & IV Probit \#4 \\
\hline Fgn-born (\%) & $\begin{array}{l}2.56^{*} \\
(9.21)\end{array}$ & $\begin{array}{l}2.60^{*} \\
(8.25)\end{array}$ & $\begin{array}{l}1.61 \\
(1.57)\end{array}$ & $\begin{array}{l}2.58^{*} \\
(8.26)\end{array}$ & $\begin{array}{l}2.45^{*} \\
(4.11)\end{array}$ \\
\hline $\begin{array}{l}\text { Wald test of } \\
\text { Exogeneity, } p>\text { chi }^{2}\end{array}$ & - & 0.15 & 0.24 & 0.11 & 0.54 \\
\hline 1880 & Probit & IV Probit \#1 & IV Probit \#2 & IV Probit \#3 & IV Probit \#4 \\
\hline Fgn-born (\%) & $\begin{array}{l}2.00^{*} \\
(8.29)\end{array}$ & $\begin{array}{l}1.25^{*} \\
(4.09)\end{array}$ & $\begin{array}{l}-0.28 \\
(0.07)\end{array}$ & $\begin{array}{l}1.24^{*} \\
(4.08)\end{array}$ & $\begin{array}{l}1.08 \\
(1.80)\end{array}$ \\
\hline $\begin{array}{l}\text { Wald test of } \\
\text { Exogeneity, } \mathrm{p}>\mathrm{chi}^{2}\end{array}$ & - & 0.03 & 0.63 & 0.02 & 0.33 \\
\hline
\end{tabular}

Note: z-statistics in parentheses. * Significant at the 5\% level. Factory is equal to 1 if a firm employed more than 15 workers and 0 otherwise. IV estimation was conducted using ivprobit in Stata version 9.

IV Probit \#1's instrument is share of foreign-born population in 1850.

IV Probit \#2's instrument is the growth in foreign-born population between 1850 and 1860.

IV Probit \#3's instruments are share of foreign-born population in 1850 and the growth in foreign-born population between 1850 and 1860 .

IV Probit \#4's instruments are distance from King's county and whether the county possessed access to water transportation in 1850 . 
Table 10

IV Estimation of Firm Size (log) of U.S. Manufacturing, 1860-1880

\begin{tabular}{|c|c|c|c|c|c|}
\hline 1860 & OLS & IV Reg \#1 & IV Reg \#2 & IV Reg \#3 & IV Reg \#4 \\
\hline Fgn-born (\%) & $\begin{array}{l}0.78 * \\
(10.5)\end{array}$ & $\begin{array}{l}0.77 * \\
(9.15)\end{array}$ & $\begin{array}{l}0.40 \\
(1.07)\end{array}$ & $\begin{array}{l}0.77 * \\
(9.12)\end{array}$ & $\begin{array}{l}1.37^{*} \\
(7.69)\end{array}$ \\
\hline $\begin{array}{l}\text { Overid test } \\
\text { Sargan P-value }\end{array}$ & - & - & - & 0.32 & 0.21 \\
\hline 1870 & OLS & IV Reg \#1 & IV Reg \#2 & IV Reg \#3 & IV Reg \#4 \\
\hline$\overline{\text { Fgn-born }(\%)}$ & $\begin{array}{l}1.15^{*} \\
(11.1)\end{array}$ & $\begin{array}{l}1.28 * \\
(10.1)\end{array}$ & $\begin{array}{l}1.34 * \\
(3.56)\end{array}$ & $\begin{array}{l}1.28 * \\
(10.2)\end{array}$ & $\begin{array}{l}1.49 * \\
(6.20)\end{array}$ \\
\hline $\begin{array}{l}\text { Overid test } \\
\text { Sargan P-value }\end{array}$ & - & - & - & 0.87 & 0.05 \\
\hline 1880 & OLS & IV Reg \#1 & IV Reg \#2 & IV Reg \#3 & IV Reg \#4 \\
\hline Fgn-born (\%) & $\begin{array}{l}1.11 * \\
(11.1)\end{array}$ & $\begin{array}{l}0.77 * \\
(5.80)\end{array}$ & $\begin{array}{l}0.88 \\
(1.17)\end{array}$ & $\begin{array}{l}0.77^{*} \\
(5.83)\end{array}$ & $\begin{array}{l}0.57 * \\
(2.18)\end{array}$ \\
\hline $\begin{array}{l}\text { Overid test } \\
\text { Sargan P-value }\end{array}$ & - & - & - & 0.88 & 0.002 \\
\hline
\end{tabular}

Note: z-statistics in parentheses. * Significant at the 5\% level. Factory is equal to 1 if a firm employed more than 15 workers and 0 otherwise.

IV Reg \#1's instrument is share of foreign-born population in 1850.

IV Reg \#2's instrument is the growth in foreign-born population between 1850 and 1860 .

IV Reg \#3's instruments are share of foreign-born population in 1850 and the growth in foreign-born population between 1850 and 1860 .

IV Reg \#4's instruments are distance from King's county and whether the county possessed access to water transportation in 1850 . 
Table 11

IV Estimation of Average Wages (log) of U.S. Manufacturing, 1860-1880

\begin{tabular}{|c|c|c|c|c|c|}
\hline 1860 & OLS & IV Reg \#1 & IV Reg \#2 & IV Reg \#3 & IV Reg \#4 \\
\hline Fgn-born (\%) & $\begin{array}{l}0.56^{*} \\
(14.0)\end{array}$ & $\begin{array}{l}0.50^{*} \\
(11.4)\end{array}$ & $\begin{array}{l}0.45^{*} \\
(2.30)\end{array}$ & $\begin{array}{l}0.50 * \\
(11.4)\end{array}$ & $\begin{array}{l}0.85^{*} \\
(9.19)\end{array}$ \\
\hline Overid test & & & & & \\
\hline Sargan P-value & - & - & - & 0.80 & 0.96 \\
\hline 1870 & OLS & IV Reg \#1 & IV Reg \#2 & IV Reg \#3 & IV Reg \#4 \\
\hline Fgn-born (\%) & $\begin{array}{l}1.31 * \\
(17.0)\end{array}$ & $\begin{array}{l}1.40^{*} \\
(15.8)\end{array}$ & $\begin{array}{l}1.37^{*} \\
(5.19)\end{array}$ & $\begin{array}{l}1.40^{*} \\
(15.8)\end{array}$ & $\begin{array}{l}1.84^{*} \\
(10.9)\end{array}$ \\
\hline $\begin{array}{l}\text { Overid test } \\
\text { Sargan P-value }\end{array}$ & - & - & - & 0.89 & 0.31 \\
\hline 1880 & OLS & IV Reg \#1 & IV Reg \#2 & IV Reg \#3 & IV Reg \#4 \\
\hline Fgn-born (\%) & $\begin{array}{l}1.54 * \\
(20.0)\end{array}$ & $\begin{array}{l}1.79 * \\
(18.0)\end{array}$ & $\begin{array}{l}1.42 * \\
(2.51)\end{array}$ & $\begin{array}{l}1.78 * \\
(18.0)\end{array}$ & $\begin{array}{l}2.36^{*} \\
(12.2)\end{array}$ \\
\hline Overid test & 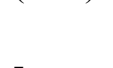 & 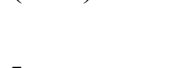 & 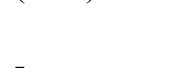 & 051 & 031 \\
\hline
\end{tabular}

Note: z-statistics in parentheses. * Significant at the 5\% level. Factory is equal to 1 if a firm employed more than 15 workers and 0 otherwise.

IV Reg \#1's instrument is share of foreign-born population in 1850.

IV Reg \#2's instrument is the growth in foreign-born population between 1850 and 1860 .

IV Reg \#3's instruments are share of foreign-born population in 1850 and the growth in foreign-born population between 1850 and 1860 .

IV Reg \#4's instruments are distance from King's county and whether the county possessed access to water transportation in 1850 . 
Table 12

IV Estimation of Labor Productivity (log) of U.S. Manufacturing, 1860-1880

\begin{tabular}{|c|c|c|c|c|c|}
\hline 1860 & OLS & IV Reg \#1 & IV Reg \#2 & IV Reg \#3 & IV Reg \#4 \\
\hline Fgn-born (\%) & $\begin{array}{l}0.93 * \\
(10.3)\end{array}$ & $\begin{array}{l}0.90 * \\
(9.13)\end{array}$ & $\begin{array}{l}0.89 * \\
(2.03)\end{array}$ & $\begin{array}{l}0.90 * \\
(9.13)\end{array}$ & $\begin{array}{l}1.85^{*} \\
(8.92)\end{array}$ \\
\hline $\begin{array}{l}\text { Overid test } \\
\text { Sargan P-value }\end{array}$ & - & - & - & 0.99 & 0.008 \\
\hline 1870 & OLS & IV Reg \#1 & IV Reg \#2 & IV Reg \#3 & IV Reg \#4 \\
\hline Fgn-born (\%) & $\begin{array}{l}1.16^{*} \\
(10.7)\end{array}$ & $\begin{array}{l}1.32 * \\
(10.3)\end{array}$ & $\begin{array}{l}0.83 * \\
(2.17)\end{array}$ & $\begin{array}{l}1.31 * \\
(10.2)\end{array}$ & $\begin{array}{l}1.84^{*} \\
(7.61)\end{array}$ \\
\hline $\begin{array}{l}\text { Overid test } \\
\text { Sargan P-value }\end{array}$ & - & - & - & 0.18 & 0.80 \\
\hline 1880 & OLS & IV Reg \#1 & IV Reg \#2 & IV Reg \#3 & IV Reg \#4 \\
\hline Fgn-born (\%) & $\begin{array}{l}1.48^{*} \\
(16.4)\end{array}$ & $\begin{array}{l}1.83^{*} \\
(15.8)\end{array}$ & $\begin{array}{l}2.02 * \\
(3.06)\end{array}$ & $\begin{array}{l}1.83 * \\
(15.9)\end{array}$ & $\begin{array}{l}2.43^{*} \\
(10.7)\end{array}$ \\
\hline $\begin{array}{l}\text { Overid test } \\
\text { Sargan P-value }\end{array}$ & - & - & - & 0.77 & 0.07 \\
\hline
\end{tabular}

Note: z-statistics in parentheses. * Significant at the 5\% level. Factory is equal to 1 if a firm employed more than 15 workers and 0 otherwise.

IV Reg \#1's instrument is share of foreign-born population in 1850.

IV Reg \#2's instrument is the growth in foreign-born population between 1850 and 1860 .

IV Reg \#3's instruments are share of foreign-born population in 1850 and the growth in foreign-born population between 1850 and 1860 .

IV Reg \#4's instruments are distance from King's county and whether the county possessed access to water transportation in 1850 . 
Table 13

Occupations in Which Foreign-born Workers are Overly Represented by National Origins:

Manufacturing, Mining and Mechanical Industries, 1870

(Average of All Gainful Workers $=100)$

\section{Germans}

bakers (587), basket-makers (424), brewing and malting (901), butchers (446), cabinet-makers (412), cigar-makers (491), confectioners (397), coopers (320), distillers and rectifiers (360), engravers (315), gun and locksmiths (382), piano (596), tailors (307), upholsterers (439), wood-turners and carvers (416)

\section{Irish}

bleachers (294), brass founders and workers (304), gas-workers (517), iron-foundry operatives (263), marble and stone cutters (319), paper-mill operatives (246), plumbers and gas fitters (269), print-work operatives (381), quarrymen (392), rolling mill operatives (264), roofers and slaters (232), rubber-factory operatives (264), sewing machine factory operatives (252), steam-boiler makers (362), wollen-mill operatives (274)

\section{English and Welsh}

bleachers, dyers and scourers (519), carpet-makers (403), cotton-mill operatives (375), iron and steel work operatives (351), iron-furnace operatives (340), knitting and hosiery mill operatives (627), machine and allied trades including engineers and foremen (309), machinists (392), mining (797), pattern making (356), pottery making (471), print-work operatives (635), rolling-mill operatives (653), silk-mill operatives (550), steam-boiler makers (436), steam-engine makers (461), tool and cutlery making (469), woolen-mill operatives (465)

\section{Scandinavian}

awning makers (563), lumbermen and raftsmen (229), saw-mill operatives (284), wood choppers (121)

\section{British American}

brick and tile (575), cotton mill operatives (454), fishermen and oystermen (383), lumbermen and raftsmen (710), oil (306), rubber factories (380), saw mill operatives (684), shingle and lath makers (455), ship-carpenters (445), shipcaulkers (325), and tool and cutlery making (427), woodchoppers (582), woolen-mill operatives (357)

\section{Occupations in Which Foreign-born Workers are Overly Represented by National Origins:}

Manufacturing and Mechanical Industries, 1890

(Average of All Gainful Workers $=100$ )

\section{Germany}

Male: bakers (515), basket-makers (303), bottlers (318), brewing and malting (813), butchers (295), cabinet-makers (427), chemical works (234), confectioners (235), coopers (233), copper workers (250), gun and locksmiths (335), lead and zinc workers (218), leather (202), meat and fruit packers, canners, preservers (232), piano (259), seamstresses (285), silk mill operatives (256), sugar makers and refiners (519), tailors (381), tobacco and cigar factory operatives (251) trunk, valise, etc. makers (264), upholsterers (207). Female: bakers (348).

\section{Ireland}

Male: bleachers (341), brass workers (229), candle, soap, tallow makers (236), carpet makers (286), chemical works (289), copper (210), gas-workers (669), hat and cap (208), iron and steel (247), leather etc. (338), marble and stone cutters (262), mason (201), meat and fruit packers, canners, preservers (269),oil (252), paper-mill operatives (256), print-work operatives (313), roofers and slaters (216), rubber-factory operatives (385), steam-boiler makers (268), sugar (209), wire (206), wollen-mill operatives (224). Female: none.

\section{Great Britain}

Male: bleachers, dyers and scourers (459), brass (216), carpet-makers (404), copper (247), cotton-mill operatives 
(340), engravers (245), glove (316), gold and silver (250), hosiery and knitting (271), iron and steel work operatives (278), machinists (266), marble and stone cutters (357), masons (206), metal works (246), mill and factory operatives (339), model and pattern making (309), potters (399), print-work operatives (386), roofers and slaters (224), sail, awning and tent (204), ship and boat (213), silk-mill operatives (386), steam-boiler makers (287), tool and cutlery making (274), woolen-mill operatives (422). Female: cotton mill operatives (261), mill and factory (323), potters (502), silk mill (228), woolen-mill (281).

\section{Canada}

Male - English speaking: builders and contractors (247), carpenters and joiners (215), rubber-factory operatives (253), sail, awning and tent (220), saw and plane mill (273), ship and boat (479). Female - English speaking: clock and watch makers (244), rubber-factory operatives (327).

Male - French speaking: boot and shoe (324), box (258), brick and tile $(1,118)$, cotton mill $(2,799)$, door, sash and blind (206), gold and silver (243), hosiery and knitting (532), leather etc. (203), mill and factory operative (934), paper mill (478), print works (377), saw and planing (405), ship and boat (280), tool and cutlery making (298), woolen-mill (736). Female - French speaking: cotton mill (1654), hosiery and knitting (281), mill and factory operative (736), woolen-mill (442).

\section{Scandinavia}

Sweden and Norway - Male: agricultural implements (467), cabinet (279), sail, awning and tent (250), saw and plane mill (341), tailors (250), wire (348). Female: none. Denmark - Male: agricultural implements (288), brick and tile (262), butter and cheese (243), cabinet (243), sail, awning and tent (269). Female: none.

\section{France}

Male: bakers (361), basket (205), bleachers, dyers and scourers (496), butchers (280), cabinet (224), charcoal, coke and lime (373), clock and watch (359), confectioners (308), copper (227), distillers and rectifiers (328), engravers (384), glass (717), glove (656), gun and locksmiths (291), lead and zinc workers (205), meat and fruit packers, canners, preservers (205), silk-mill operatives (838). Female: artificial flower (739), bakers (254), bleachers, dyers and scourers (851), confectioners (211), glass (271), lace and embroidery (413), silk-mill (238).

\section{Italy}

Male: boot and shoe (268), charcoal, coke and lime (476), confectioners (771), distillers and rectifiers (308), hat and cap (256), marble and stone (464), print works (234), silk mill (509). Female: artificial flower (3788), bakers (348), bleachers, dyers and scourers (232), confectioners (2554), paper mill (416), sewing machine operators (276), silk mill (319), Tailoresses (726), tobacco and cigar factory (421)

Source: Hutchinson (1956).

Note: Only those with figures greater than 200 have been listed. 
Table 14

Summary Statistics: 1880 and 1920

(mean values)

\begin{tabular}{lll}
\hline All Firms & 1880 & 1920 \\
\hline Urban (\%) & 31.6 & 54.6 \\
Foreign-born (\%) & 20.7 & 19.2 \\
Male (\%) & 51.0 & 51.3 \\
Age (log) & 3.48 & 3.55 \\
Single (\%) & 33.5 & 29.6 \\
Literate (\%) & 82.9 & 93.0 \\
Observations & 301,499 & 696,927
\end{tabular}

Note: Data are from 1880 and 1910 IPUMS. Samples were restricted to individuals of 16 years and older and for those whose literacy and urban statuses were identified.

Table 15

Determinants of Urban Location of Individuals, 1880 and 1920

(Logit Regression Reported in Odds-Ratio)

\begin{tabular}{|c|c|c|c|c|c|c|c|c|}
\hline \multirow[t]{2}{*}{ Urban } & \multicolumn{4}{|c|}{1880} & \multicolumn{3}{|c|}{1920} & \multirow[b]{2}{*}{$\left(4^{\prime}\right)$} \\
\hline & (1) & (2) & (3) & (4) & $\left(1^{\prime}\right)$ & $\left(2^{\prime}\right)$ & $\left(3^{\prime}\right)$ & \\
\hline Fgn-born & $\begin{array}{l}3.60^{*} \\
(137)\end{array}$ & $\begin{array}{c}3.75^{*} \\
(136)\end{array}$ & $\begin{array}{l}3.47^{*} \\
\text { (111) }\end{array}$ & $\begin{array}{l}3.25^{*} \\
(93.6)\end{array}$ & $\begin{array}{l}3.04 * \\
(162)\end{array}$ & $\begin{array}{c}3.46^{*} \\
(174)\end{array}$ & $\begin{array}{l}3.18^{*} \\
(140)\end{array}$ & $\begin{array}{l}2.15^{*} \\
(85.1)\end{array}$ \\
\hline Male & - & $\begin{array}{l}0.79^{*} \\
(28.7)\end{array}$ & $\begin{array}{l}0.63^{*} \\
(24.6)\end{array}$ & $\begin{array}{l}0.66^{*} \\
(20.3)\end{array}$ & - & $\begin{array}{l}0.85^{*} \\
(31.7)\end{array}$ & $\begin{array}{l}0.81^{*} \\
(22.0)\end{array}$ & $\begin{array}{l}0.85^{*} \\
(15.6)\end{array}$ \\
\hline Age & - & $\begin{array}{l}1.02 \\
(1.57)\end{array}$ & $\begin{array}{l}1.11 * \\
(7.37)\end{array}$ & $\begin{array}{l}0.85^{*} \\
(10.9)\end{array}$ & - & $\begin{array}{l}0.99^{*} \\
(2.14)\end{array}$ & $\begin{array}{l}1.12 * \\
(14.1)\end{array}$ & $\begin{array}{l}0.94 * \\
(6.62)\end{array}$ \\
\hline Single & - & $\begin{array}{l}1.39 * \\
(30.2)\end{array}$ & $\begin{array}{l}1.03^{*} \\
(2.26)\end{array}$ & $\begin{array}{l}0.95^{*} \\
(3.41)\end{array}$ & - & $\begin{array}{l}1.23^{*} \\
(32.9)\end{array}$ & $\begin{array}{l}0.94^{*} \\
(8.02)\end{array}$ & $\begin{array}{l}0.85^{*} \\
(19.8)\end{array}$ \\
\hline Literate & - & $\begin{array}{l}2.51^{*} \\
(71.4)\end{array}$ & $\begin{array}{l}2.16^{*} \\
(52.9)\end{array}$ & $\begin{array}{l}1.52^{*} \\
(24.7)\end{array}$ & - & $\begin{array}{l}2.32 * \\
(82.6)\end{array}$ & $\begin{array}{l}1.73^{*} \\
(45.5)\end{array}$ & $\begin{array}{l}1.33^{*} \\
(21.5)\end{array}$ \\
\hline \multicolumn{9}{|l|}{ Fixed-effects } \\
\hline Occupation & no & no & yes & yes & no & no & yes & yes \\
\hline State & no & no & no & yes & no & no & no & yes \\
\hline \multicolumn{9}{|l|}{ Pseudo } \\
\hline R-squared & 0.05 & 0.07 & 0.25 & 0.33 & 0.03 & 0.04 & 0.25 & 0.31 \\
\hline Observations & 301,499 & 301,499 & 301,354 & 301,123 & 696,927 & 696,927 & 696,809 & 693,518 \\
\hline
\end{tabular}

Note: $\mathrm{z}$-statistics in parentheses. * Significant at the $5 \%$ level.

Data are from 1880 and 1910 IPUMS. Samples were restricted to individuals of 16 years and older and for those whose literacy and urban statuses were identified. Occupation fixed-effects were constructed using 1950

occupational categories. 


\section{References}

Acemoglu, Daron. 1998. "Why Do New Technologies Complement Skills? Directed Technical Change and Wage Inequality," Quarterly Journal of Economics 113 (4): 10551189.

Albion, Robert G. 1939 [1984 reprint]. The Rise of New York Port 1815-1860. Boston: Northeastern University Press.

Altonji, Joseph and David Card. 1991. "The Effects of Immigration on the Labor Market Outcomes of Less-Skilled Natives," in J. Abowd and R. Freedman, eds. Immigration, Trade and the Labor Market. Chicago: University of Chicago Press.

Atack, Jeremy. 1987. "Economies of Scale and Efficiency Gains in the Rise of the Factory in America, 1820-1920," in P. Kilby, ed., Quantity and Quidity: Essays in U.S. Economic History. Middletown: Wesleyan University Press.

Atack, Jeremy and Fred Bateman. 1999. "U.S. Historical Statistics: Nineteenth-Century U.S. Industrial Development through the Eyes of the Census of Manufactures," Historical Methods 32 (4): 177-188.

Atack, Jeremy, Fred Bateman and Robert Margo. 2004. "Skill Intensity and Rising Wage Dispersion in Nineteenth-Century American Manufacturing," Journal of Economic History 64 (1):172-192.

Atack, Jeremy, Fred Bateman and Robert Margo. 2005. "Capital Deepening and the Rise of the Factory: The American Experience in the Nineteenth Century" Economic History Review 58 (3): 586-595.

Atack, Jeremy and Peter Passell. 1994. A New Economic View of American History from Colonial Times to 1940. 2nd Ed. New York: W.W. Norton \& Co.

Autor, David H., Frank Levy, and Richard J. Murnane. 2003. "The Skill Content of Recent Technological Change: An Empirical Exploration," Quarterly Journal of Economics 118 (4): 1279-1334.

Barrett, James R. 1987. Work and Community in the Jungle: Chicago's Packinghouse Workers 1894-1922. University of Illinois Press.

Bartel, Ann P. 1989. "Where Do the New U.S. Immigrants Live?” Journal of Labor Economics 7, 371-391.

Beaudry, Paul and David A. Green. 2005. "Changes in U.S. Wages, 1976-2000: Ongoing Skill Bias or Major Technological Change?” Journal of Labor Economics 23 (3): 609-648.

Becker, Gary S. and Kevin M. Murphy. 1992. "The Division of Labor, Coordination Costs and Knowledge," Quarterly Journal of Economics 107 (4): 1137-1160.

Berman, Eli, John Bound, and Zvi Griliches. 1994. "Changes in the Demand for Skilled Labor within U.S. Manufacturing Industries: Evidence from the Annual Survey of Manufacturing," Quarterly Journal of Economics 109: 367-397.

Blau, Francine. 1980. "Immigration and Labor Earnings in Early Twentieth Century America," Research in Population Economics 2: 21-41.

Bodnar, John. 1977. Immigration and Industrialization: Ethnicity in an American Mill Town, 1870-1940. University of Pittsburgh Press.

Bodnar, John, Roger Simon and Michael P. Weber. 1982. Lives of Their Own: Blacks, Italians, and Poles in Pittsburgh, 1900-1960. Urbana: University of Illinois Press.

Bogue, Donald J. 1959. The Population of the United States. The Free Press. 
Borjas, George. 1995. "Ethnicity, Neighborhoods, and Human-Capital Externalities," American Economic Review 85, 365-390.

Borjas, George. 1999. Heaven's Door: Immigration Policy and the American Economy. Princeton University Press.

Borjas, George, Richard B. Friedman, and Lawrence F. Katz. 1997. "How Much Do Immigration and Trade Affect Labor Market Outcomes," Brookings Papers on Economic Activity 1, 1-90.

Burrows, Edwin G. and Mike Wallace. 1999. Gotham: A History of New York City to 1898. New York: Oxford University Press.

Cain, Louis P. and Donald G. Paterson. 1986. "Biased Technical Change, Scale and Factor Substitution in American Industry, 1850-1919," Journal of Economic History 46: 153164.

Card, David. 2001. "Immigrant Inflows, Native Outflows, and the Local Labor Market Impacts of Higher Immigration," Journal of Labor Economics 19, 22-64.

Carpenter, Niles. 1927. Immigrants and Their Children 1920. U.S. GPO.

Cohn, Raymond L. 1992. "The Occupations of English Immigrants to the U.S., 1836-1853," Journal of Economic History 65 (2): 469-495.

Cohn, Raymond L. 2000. "Nativism and the End of the Mass Migration of the 1840s and 1850s," Journal of Economic History 60 (2): 361-383.

Cohn, Raymond L. 2005. "The Transition from Sail to Steam in Immigration to the United States," Journal of Economic History 65 (2): 469-495.

Cohn, Raymond L. 2006. "Immigration to the United States," EH.net. Encyclopedia.

Collins, William J. 1997. "When the Tide Turned: Immigration and the Delay of the Great Migration," Journal of Economic History 57: 607-632.

Coombes, Whitney. 1926. The Wages of Unskilled Labor in Manufacturing Industries in the United States, 1890-1924. New York: Columbia University Press.

David, Paul A. 1975. Technology Choice, Innovation and Economic Growth. Cambridge: Cambridge University Press.

Demsetz, Harold. 1988. "The Theory of the Firm Revisited," Journal of Law, Economics and Organization 4 (1): 141-161.

Earnst, Robert. [1949] 1994. Immigrant Life in New York City 1825-1863. Syracuse: Syracuse University Press.

Edin, Per-Anders, Peter Fredricksson, and Olof Åslund. 2003. "Ethnic Enclaves and the Economic Success of Immigrants - Evidence from a Natural Experiment," Quarterly Journal of Economics 118, 329-357.

Eichengreen, Barry and Henry A. Gemery. 1986. "The Earnings of Skilled and Unskilled Immigrants at the End of the Nineteenth Century," Journal of Economic History 46: 441454.

Erickson, Charlotte. 1957. American Industry and the European Immigrant 1860-1885. Cambridge: Harvard University Press.

Feldman, Egal. 1960. Fit for Men: A Study of New York's Clothing Trade. Washington DC: Public Affairs Press.

Ferrie, Joseph P. 1999. Yankeys Now: Immigrants in the Antebellum U.S. 1840-1860. Oxford University Press.

Filer, Randall. 1992. “The Impact of Immigrant Arrivals on Migratory Patterns of Native 
Workers," in Immigration and the Work Force: Economic Consequences for the United States and Source Areas, G. Borjas and R. Freeman, eds., Chicago: University of Chicago Press.

Friedberg, Rachel M. and Jennifer Hunt. 1995. "The Impact of Immigrants on Host Country Wages, Employment and Growth,” Journal of Economic Perspectives 9 (2): 23-44.

Galenson, David W. 1984. "The Rise and Fall of Indentured Servitude in the Americas: An Economic Analysis," Journal of Economic History 44: 1-26.

Gibson, Campbell J. and Emily Lennon. 1999. "Historical Census Statistics on the Foreignborn Population of the United States: 1850-1990," Population Division Working Paper No. 29, U.S. Bureau of the Census.

Goldin, Claudia. 1990. Understanding the Gender Gap: An Economic History of American Women. New York: Oxford University Press.

Goldin, Claudia. 1994. "The Political Economy of Immigration Restriction in the United States, 1890-1921," in The Regulated Economy, edited by C. Goldin and G. Libecap. University of Chicago Press.

Goldin, Claudia. 2001. "The Human-Capital Century and American Leadership: Virtues of the Past," Journal of Economic History 61 (2): 263-292.

Goldin, Claudia and Lawrence F. Katz. 1998. "The Origins of Technology-Skill Complementarity," Quarterly Journal of Economics 113 (3): 693-732.

Goldin, Claudia and Lawrence F. Katz. 1999. "The Returns to Skill Across the Twentieth Century United States," mimeo.

Goldin, Claudia and Lawrence F. Katz. 2000. "Education and Income in the Early Twentieth Century: Evidence from the Prairies," Journal of Economic History 60 (3): 782-818.

Goldin, Claudia and Robert A. Margo. 1992. "The Great Compression: The Wage Structure in the United States at Mid-Century," Quarterly Journal of Economics 107 (1): 1-34.

Goldin, Claudia and Kenneth L. Sokoloff. 1982. "Women, Children, and Industrialization in the Early Republic: Evidence from the Manufacturing Censuses," Journal of Economic History 42 (4): 741-774.

Habakkuk, H. J. 1962. American and British Technology in the Nineteenth Century: The Search for Labour-Saving Inventions. Cambridge: Cambridge University Press.

Hamilton, Gillian. 2000. "The Decline of Apprenticeship in North America: Evidence from Montreal," Journal of Economic History 60 (3): 627-664.

Hanes, Christopher L. 1996. "Immigrants' Relative Rate of Wage Growth in the Late 19th Century," Explorations in Economic History 33: 35-64.

Hannon, Joan. 1982. "Ethnic Discrimination in a 19th-Century Mining District: Michigan Copper Mines, 1888," Explorations in Economic History 19: 28-50.

Hanson, Gordon H. and Matthew J. Slaughter. 2002. "Labor-Market Adjustments in Open Economies: Evidence from US States,” Journal of International Economics 57 (1): 3-29.

Hatton, Timothy. 1997. "The Immigration Assimilation Puzzle in Late Nineteenth-Century America," Journal of Economic History 57: 34-62.

Hatton, Timothy J. and Jeffrey G. Williamson. 1998. The Age of Mass Migration. Oxford University Press.

Hatton, Timothy J. and Jeffrey G. Williamson. 2005. Global Migration and the World Economy: Two Centuries of Policy and Performance. Cambridge: MIT Press.

Hingham, John. [1955] 1994. Strangers in the Land: Patterns of Nativism, 1860-1925. New 
Brunswick: Rutgers University Press.

Hutchinson, E.P. 1956. Immigrants and Their Children, 1850-1950. John Wiley \& Sons.

James, John A. and Jonathan S. Skinner. 1985. "The Resolution of the Labor-Scarcity Paradox," Journal of Economic History 45: 513-540.

Jerome, Harry. 1934. Mechanization in Industry. New York: NBER.

Keeling, Drew. 1999. "The Transportation Revolution and Transatlantic Migration, 1850-1914," Research in Economic History 19: 39-74.

Kim, Sukkoo. 1995. "Expansion of Markets and the Geographic Distribution of Economic Activities: The Trends in U.S. Regional Manufacturing Structure, 1860-1987," Quarterly Journal of Economics 110 (4): 881-908.

Kim, Sukkoo. 1999. "Regions, Resources, and Economic Geography: The Sources of U.S. Regional Comparative Advantage, 1880-1987," Regional Science and Urban Economics 29 (1): 1-32.

Kim, Sukkoo. 2000. "Urban Development in the United States, 1690-1990," Southern Economic Journal 66 (4): 855-880.

Kim, Sukkoo. 2005. "Industrialization and Urbanization: Did the Steam Engine Contribute to the Growth of Cities in the United States?" Explorations in Economic History 42: 586-598.

Kim, Sukkoo. 2006. "Division of Labor and the Rise of Cities: Evidence from U.S. Industrialization, 1850-1880," Journal of Economic Geography 6: 469-491.

Lebergott, Stanley. 1964. Manpower in Economic Growth. New York: McGraw Hill.

Lewis, Ethan. 2003. "Local, Open Economies Within the US: How Do Industries Respond to Immigration?" mimeo.

Lewis, Ethan. 2006. "Immigration, Skill Mix, and the Choice of Technique," mimeo.

Long, Clarence D. 1960. Wages and Earnings in the United States 1860-1890. Princeton: Princeton University Press.

Margo, Robert A. 2000. Wages and Labor Markets in the United States, 1820-1860. Chicago: University of Chicago Press.

McClelland, Peter D. and Richard J. Zeckhauser. 1982. Demographic Dimensions of the New Republic: American Interregional Migration, Vital Statistics, and Manumissions, 18001860. Cambridge: Cambridge University Press.

Minn, Chris. 2000. "Income, Cohort Effects, and Occupational Mobility: A New Look at Immigration to the United States at the Turn of the Twentieth Century," Explorations in Economic History 37: 326-350.

Mokyr, Joel. 1985. Why Ireland Starved: An Analytical and Quantitative History of the Irish Economy, 1800-1850. 2nd ed. London: Allen and Unwin.

Mokyr, Joel. 1999. "Editor's Introduction: The New Economic History and the Industrial Revolution," in The British Industrial Revolution, $2^{\text {nd }}$ Edition. Boulder: Westview Press.

Mokyr, Joel. 2002. The Gifts of Athena: Historical Origins of the Knowledge Economy. Princeton: Princeton University Press.

O'Brien, Anthony P. 1988. "Factory Size, Economies of Scale, and the Great Merger Wave of 1898-1902," Journal of Economic History 48 (3): 639-649.

Ó Gráda, Cormac. 1999. Black '47 and Beyond: The Great Irish Famine. Princeton: Princeton University Press.

Ó Gráda, Cormac and Kevin H. O’Rourke. 1997. "Migration as Disaster Relief: Lessons from the Great Irish Famine. European Review of Economic History 1: 3-25. 
Ottaviano, Gianmarco I.P. and Giovanni Peri. 2005a. "Cities and Cultures," Journal of Urban Economics, forthcoming.

Ottaviano, Gianmarco I.P. and Giovanni Peri. 2005b. "Rethinking the Gains from Immigration: Theory and Evidence from the U.S.," Journal of Economic Geography, forthcoming.

Pope, Jesse E. 1905 [1970]. The Clothing Industry in New York. New York: Burt Franklin.

Rees, Albert. 1961. Real Wages in Manufacturing 1890-1914. Princeton: Princeton University Press.

Rischin, Moses. 1962. The Promised City: New York Jews 1870-1914. Harvard University Press.

Rosenberg, Nathan. 1972. Technology and American Economic Growth. New York: Harper \& Row.

Sokoloff, Kenneth L. 1984. "Was the Transition from the Artisanal Shop to the Nonmechanized Factory Associated with Gains in Efficiency?: Evidence from the U.S. Manufacturing Censuses of 1820 and 1850," Explorations in Economic History 21: 351-382.

Staiger, Douglas and James H. Stock. 1997. "Instrumental Variables Regression with Weak Instruments," Econometrica 65(3): 557-586.

Steinfeld, Robert J. 2001. Coercion, Contract, and Free Labor in the Nineteenth Century. Cambridge: Cambridge University Press.

Stott, Richard B. 1990. Workers in the Metropolis: Class, Ethnicity, and Youth in Antebellum New York City. Ithaca: Cornell University Press.

Temin, Peter. 1966. "Labor Scarcity and the Problem of American Industrial Efficiency in the 1850s," Journal of Economic History 26: 277-298.

Thomas, Brinley. 1954. Migration and Economic Growth: A Study of Great Britain and the Atlantic Economy. Cambridge: Cambridge University Press.

Treffler, Daniel. 1995. "The Case of the Missing Trade and Other Mysteries," American Economic Review 85 (5): 1029-1046.

U.S. Senate. 1911. Reports of the Immigration Commission. 42 Volumes. Washington DC: GPO.

Waldinger, Roger D. 1986. Through the Eye of the Needle: Immigrants and Enterprise in New York's Garment Trades. New York: New York University Press.

Ward, David. 1972. Cities and Immigrants: A Geography of Change in Nineteenth Century America. New York: Oxford University Press.

Ward, David. 1989. Poverty, Ethnicity, and the American City, 1840-1925. Cambridge: Cambridge University Press.

Williamson, Jeffrey G. 1990. Coping with City Growth during the British Industrial Revolution. Cambridge: Cambridge University Press.

Williamson, Jeffrey G. and Peter H. Lindert. 1980. American Inequality: A Macroeconomic History. New York: Academic Press.

Wright, Richard A. and Mark Ellis and Michael Reibel. 1997. "The Linkage Between Immigration and Internal Migration in Large Metropolitan Areas in the United States," Economic Geography 73, 234-254. 